\title{
НЕСУИЦИДАМЬНЫЕ САМОПОВРЕЖДЕНИЯ ПОДРОСТКОВ: ОБЩЕЕ И ОСОБЕННОЕ. Часть I.
}

\author{
Е.Б. Аюбов, П.Б. Зотов
}

Московский НИИ психиатрии - филиал ФГБУ «Национальный медицинский исследовательский центр психиатрии и наркологии им. В.П. Сербского" Минздрава России, г. Москва, Россия ФГБОУ ВО “Тюменский государственный медицинский университет» Минздрава России, г. Тюмень, Россия

\section{ADOLESCENTS NON-SUICIDAL SELF-INJURY: GENERAL AND PARTICULAR. Part I.}

\section{E.B. Lyubov, P.B. Zotov}

Moscow Institute of Psychiatry - branch of National medical research center of psychiatry and narcology by name V.P. Serbsky, Moscow, Russia

Tyumen State Medical University, Tyumen, Russia

Информация об авторах:

Аюбов Евгений Борисович - доктор медицинских наук, профессор (SPIN-код: 6629-7156; Researcher ID: B5674-2013; ORCID iD: 0000-0002-7032-8517). Место работы и должность: главный научный сотрудник отдемения клинической и профимактической суицидомогии Московского научно-исследовательского института психиатрии филиала ФГБУ “Национальный медицинский исследовательский центр психиатрии и наркологии им. В.П. Сербского" Минздрава России. Адрес: Россия, 107076, г. Москва, ум. Потешная, д. 3, корп. 10. Телефон: +7 (495) 963-75-72, эмектронный адрес: lyubov.evgeny@mail.ru

Зотов Павец Борисович - доктор медицинских наук, профессор (SPIN-код: 5702-4899; Researcher ID: U-28072017; ORCID iD: 0000-0002-1826-486X). Место работы и должность: заведующий кафедрой онкологии ФГБОУ ВО "Тюменский государственный медицинский университет" Минздрава России. Адрес: Россия, 625023, г. Тюмень, ул. Одесская, д. 54; специалист центра суицидальной превенции ГБУЗ ТО “Областная клиническая психиатрическая больница". Адрес: Тюменская область, Тюменский район, р.п. Винзили, ул. Сосновая, д. 19. Телефон: +7 (3452) $270-$ 510, эмектронный адрес (корпоративный): note72@уandex.ru

Information about the authors:

Lyubov Evgeny Borisovich - MD, PhD, Professor (SPIN-code: 6629-7156; Researcher ID: B-5674-2013; ORCID iD: 0000-0002-7032-8517). Place of work: Chief Researcher, Clinical and Preventive Suicidology Division, Moscow Research Institute of Psychiatry, a branch of the National Medical Research Center for Psychiatry and Narcology named after V.P. Serbsky. Address: Russia, 107076, Moscow, 3/10 Poteshnaya str. Phone: +7 (495) 963-75-72, email: lyubov.evgeny@mail.ru

Zotov Pavel Borisovich - MD, PhD, Professor (SPIN-code: 5702-4899; Researcher ID: U-2807-2017; ORCID iD: 00000002-1826-486X). Place of work: Head of the Department of Oncology, Tyumen State Medical University. Address: Russia, 625023, Tyumen, 54 Odesskaya str; Specialist of the Center for Suicidal Prevention of Regional Clinical Psychiatric Hospital. Address: Tyumen region, Vinzili, 19 Sosnovaya str. Phone: +7 (3452) 270-510, email (corporate): note72@yandex.ru

В первой части обзора самоповреждающее поведение («селф-харм», СX) рассмотрено как спектр прямых и непрямых форм девиантного поведения с акцентом на несуицидальное СX подростков в сопоставлении со старшими возрастами и учётом гендерного аспекта. Уточнены распространённость, возможно, растущая, СX в клинических и популяционных выборках, функции СХ; обсуждены модели (гипотезы) СX и взаимосвязи несуицидального и суицидального поведения.

Ключевые слова: самоповреждения, несуицидальные самоповреждения, распространённость, факторы риска

Счастье или несчастье человека в основном является делом его собственных рук. Дю. Локк

Боль хочет, чтобы её чувствовали. Дж. Грин «Виноватьл звездыл»

Намеренное самоповреждение» (deliberate selfharm; англицизм «селф-харм», или далее - CX) coпровождает историю человечества [1].

Бесноватый «ночью и днём, в горах и гробах, кричал и бился о камни» (Мк.5:1-14), но излечен Иисусом.

Научный, клинический и общественный интерес к СХ вырос. Так, при использовании поискового сло-
A person's happiness or unhappiness is mainly the work of his own hands.

J. Locke

Pain wants to be felt.

J. Green. "The Stars are to blame"

Intentional self-harm "(deliberate selfharm, self-injury, further on the text $\mathrm{SH}$ ) accompanies the history of mankind [1].

The demon-possessed "was crying and gashing himself with the stones night and day, in the mountains and among tombs" (Mark 5: 1-14), but he was healed by Jesus.

Scientific, clinical and public interest in 
ва «несуицидальное самоповреждение» в поисковой базе PubMed более 25000 источников за последние 10 лет.

Изучение CX (подростков) - важная научно практическая проблема в нескольких аспектах:

1) масштабов клинико-социального и экономического бремени для пациента, его близких, медицинских служб и общества в целом [2];

2) в свете лучшего понимания природы пагубного (рискованного) для здоровья поведения, включая злоупотребление психоактивных веществ (ПАВ) и

$3)$ суицидального поведения (СП) [3, 4].

Игнорирование психических расстройств в основе СХ и СП подростков чревато неблагоприятными последствиями по мере взросления: ухудшением физического и психического благополучия и ограничениями полноценной (качественной) жизни.

Метод. Обзор литературы основан на выборочном поиске в PubMed, PsycINFO, Cochrane Library базах данных с особым вниманием к группам высокого риска, используя поисковые термины «adolesc, NSSI, self-harm». Включены уместные русскоязычные исследования.

Определения . Б.Шоу

Всякая профессия - заговор против непосвящённого.

Подростковыци возраст - переходный период развития человека между детством и зрелостью. Согласно терминологии Фонда ООН в области народонаселения, подростки 10-19 лет (ранний подростковый возраст 10-14 лет; поздний подростковый возраст 15-19 лет) - каждый шестой землянин.

Обычно в литературе о СХ подростки (12-17 лет) и молодые (18-25 лет) формально разделены при обобщённой оценке [5].

Описание «психотипа» подростков традиционно иронично-нелицеприятно с тягой к морализаторству. Но важный общий смысл прослежен взрослыми веками: они - «другие».

Аристотелевы «пьяные без вина» подростки «... обожают роскошь, у них плохие манеры и нет никакого уважения к авторитетам ... выказывают неуважение к старшим, слоняются без дела и постоянно сплетничают ... всё время спорят с родителями, они постоянно вмешиваются в разговоры и привлекают к себе внимание, они прожорливы и тиранят учителей. Сократ.

Хотел бы я, чтобы между шестнадцатью и двадцатью годами не было никакого возраста или чтобы молодёжь могла проспать это время; а то ведь в эти годы у них только и дела, что делать девкам детей, обирать стариков, воровать да драться. Шекспир «Зимняя сказка».

...для подростка нормально вести себя достаточно длительное время несоответствующим и непредсказуемым образом; бороться с влечениями и в то же время принимать их, противостоять и поддаваться им; любить родителей и ненавидеть их, восставать против них и зависеть от них, глубоко стыдиться посвящать свою мать во все свои дела и
SH has grown. So, when using the search word "non-suicidal self-harm" in the PubMed search base, there are more than 25,000 sources over the past 10 years.

The study of (adolescents) $\mathrm{SH}$ is an important scientific and practical issue due to several aspects:

1) in the scale of the clinical, social and economic burden for the patient, their relatives, medical services and society as a whole [2];

2) in terms of a better understanding of the nature of harmful (risky) health behavior, including substance abuse and

3) suicidal behavior (SB) [3, 4].

Ignoring mental disorders that underlie adolescents $\mathrm{SH}$ and SB is fraught with adverse consequences as they grow up: a deterioration in physical and mental well-being and limitations of a full (quality) life.

Method. The literature review is based on selective searches of PubMed, PsycINFO, Cochrane Library databases with a particular focus on high-risk groups using search terms "adolesc, NSSI, self-harm". Relevant Russian language studies included.

Definitions.

All professions are conspiracies against the laity. B. Shaw.

Adolescence is a transitional period of human development between childhood and maturity. According to the terminology of the United Nations Population Fund, adolescents are individuals aged 10-19 (10-14 is considered early adolescence and 15-19 is considered late adolescence) and every sixth human on earth is adolescent.

Usually in the literature on $\mathrm{SH}$, adolescents (12-17 years old) and young people (1825 years old) are formally separated in the generalized assessment [5].

The description of the adolescent "psychotype" is traditionally ironic and impartial with a tendency for moralizing. But an important general meaning has been traced by adult for ages: they are "different".

Aristotle's teenagers who are "drunk without wine"... adore luxury, have bad manners and have no respect for authorities ... show disrespect to their elders, hang around and gossip constantly ... argue with their parents all the time, they constantly interfere in conversations and attract attention, they are gluttonous and tyrannize teachers. Socrates.

"I wish there were no age between ten and three-and-twenty, or that youth would sleep out the rest; for there is nothing in the between but getting wenches with child, wronging the ancientry, stealing, fighting." Shakespeare. "The Winter's Tale".

... it is normal for a teenager to behave in an inappropriate and unpredictable manner for a sufficiently long time; to fight with their drives and at the same time accept them, resist and give in to 
жаждать разговора с ней по душам; успешно идентифицироваться с другими, пока идёт неустанный поиск своей собственной идентичности; быть более идеалистичным, артистичным, искренним и бескорыстным, чем когда-либо в дальнейшем, но и наоборот, эгоистичным, самодовольным, расчётливым. Такие колебания между крайними противоположностями были бы расценены как стопроцентно патологические в любой другой период жизни... Эго индивида не прекращает экспериментировать. А. Фрейд.

Поколение «зет», 1996-2017 г.р. самое разнообразное и многокультурное поколение; по самоописаниям, глобалисты с быстроменяющейся самоидентификацией, нарушители правил и технические аборигены: социальные медиа, технологии и киберзапугивание оказывают наибольшее влияние.

Поколение снежинок (Generation Snowflake) ироничное обозначение поколения, взрослеющего вместе с XXI веком; подчёркивает уязвимость молодых и их уверенность в своей исключительности.

Детство и подростковый период признаны ВО3 критическими этапами жизненного цикла, в ходе которых формируются закономерности поведения, предопределяющие текущее состояние здоровья и показатели здоровья в будущем [6].

Подростковый возраст - период значимых неврологических и биологических сдвигов, проблем учёбы и работы, романтических отношений, роста ответственности и независимости.

Когда мне было четырнадцать лет, мой отец был так глуп, что я с трудом переносил его. Когда мне исполнился двадцать один, я был изумлён, как поумнел старик за эти семь лет! М. Твен

В итоге кумуляции генетических, биологических, психиатрических, психосоциальных и культурных воздействий СХ приурочены к началу полового созревания [7].

Противна молодость. Противна!

Признаем это объективно.

Она собой упоена,

Хотя не может ни хрена.

Она навязчива, болтлива,

Глупа, потлива, похотлива,

Смешна гарольдовым плащом

И вулканическим прыщом.

Д. Быков «Прощзай, молодость»

Вероятно, сейчас я счастливее, чем прежде, и всё же должен признать, что променял бы всего себя, такого, каким стал, на то, чтобы быть тобой, вечно несчастным, нервным, диким, недоумевающим и отчаявшимся 16летним Стивеном. Злым, объятым тревогой и несуразным, но живым. Потому что ты умеешь чувствовать, а уметь чувствовать - важнее, чем то, как себя чувствуешь. Омертвление души - единственное непростительное преступление, а если счастье на что-то и способно, так это на то, чтобы замаскировать омертвление души. $\mathrm{Cm}$. Фрай

Разнообразные физические, эмоциональные и социальные изменения, в том числе воздействие факторов бедности, жестокого обращения или насилия, them; love parents and hate them, rebel against them and depend on them, they are deeply ashamed to devote their mothers to all their affairs and yearn for a heart-to-heart conversation with her; successfully identify with others while there is a relentless search for one's own identity; be more idealistic, artistic, sincere and unselfish than ever later, but conversely, selfish, self-righteous, calculating. Such fluctuations between extreme opposites would be regarded as one hundred percent pathological in any other period of life ... The ego of the individual does not stop experimenting. A. Freud.

Generation Z, born between 1996 and 2017 , is the most diverse and multicultural generation; according to their self-reports they are globalists with fast shifting identities, rule breakers and tech natives: social media, technology, and cyberbullying have the greatest impact.

Generation Snowflake is an ironic designation of a generation growing up with the $21 \mathrm{st}$ century; emphasizes the vulnerability of young people and their confidence in their exclusivity.

Childhood and adolescence are recognized by WHO as critical stages of the life cycle, during which behavioral patterns are formed that determine the current state of health and health indicators in the future [6].

Adolescence is a period of significant neurological and biological shifts, problems at study and work, romantic relationships, growth of responsibility and independence.

When I was fourteen years old, my father was so stupid that I could hardly bear him. When I turned twenty-one, I was amazed how the old man had grown wiser in these seven years! M. Twain.

As a result, the cumulation of genetic, biological, psychiatric, psychosocial and cultural influences of SH are timed to the onset of puberty [7].

Youth is disgusting. Disgusting!

We admit this objectively.

It is intoxicated with itself

But it can fucking nothing.

It is obsessive, talkative

Foolish, sweating, lustful,

Funny with the Harold's cloak

And a volcanic pimple.

D. Bykov. "Goodbye youth"

I'm probably happier now than before, and yet I have to admit that I would trade all of myself, the way I've become, for being you, the eternally unhappy, nervous, wild, bewildered and desperate 16-year-old Stephen. Angry, anxious and awkward, but alive. Because you can feel, and knowing how to feel is more important than how you feel. The death of the soul is the only unforgivable crime, and if happiness is capable of anything, it is to disguise the death of the soul. St. Fry.

Different physical, emotional and social changes, including exposure to poverty, abuse or violence, increase adolescents' vulnerability to developing mental health problems in adulthood. 
усиливают уязвимость подростков к развитию психических расстройств во взрослой жизни.

Как постичь великолепие и полноту юности, если все силы уходят на борьбу с ошибками, с лживыми догмами родителей и длинной вереницы предков? Разве главное земное предназначение молодости - бунтовать, разрушать, убивать? Разве для того даётся молодость, чтобы приносить её в жертву? А юные мечты?! Всегда ли их считать глупыми причудами возраста? Мечты - побеги и почки воображения. Попробуйте задушить или исказить юношеские мечты, и вы уничтожите их творца. Там, где не было подлинной юности, невозможна подлинная зрелость.... Г.Миллер. «Время убийи»

«Поколением снежинок» (snowflake generation) назвали рождённых в странах золотого миллиарда после 1990 гг. Самые большие хороводы снежинок в старших классах приличных школ. Беззаботные сытые снежинки (представили?) ненавидят насилие (так им кажется); превыше всего безопасность (в том числе эмоциональная); обостренно чувствительны, мнительны и впечатлительны; не привычны к лишениям, тяжелому труду, грубому обращению; нетерпимы к оппонентам; видят историю чередой преступлений, от коих отрекаются (от мировой литературы тоже); убеждены в уникальности и высоко себя ценят; обладают ограниченной фантазией; при несовпадении представлений с реальной жизнью сильный стресс; охотно делятся интимными переживаниями; политкорректные левые детоцентристы с феминистскими взглядами, вегетарианцы; не терпят тишины и одиночества.

Историческая перспектива СX.

Несмертельные и преднамеренные формы СХ рассмотрены как попытки самоубийства, независимо от намерения добровольно умереть [8].

В дополнение к дискуссии о мотивации, ипостаси СХ привело к путанице. «Буря»

Научить словам - не дать «знание вещей» Шекспир

Ничто так не враждебно точности суждения, как недостаточное различение. Э. Берк

Термины «парасуицид» [9], «самоповреждения» (self-injury), CX, «несмертельное преднамеренное самоповреждение» (non-fatal deliberate self-harm) использованы для СХ поведения, не влекущего смерти, независимо от намерения самоубийства. Однако вслед парасуициду нередко «истинное» СП. По определению ВОЗ (1982), парасуицид и суицидальная попытка (незавершённый суицид) синонимичны.

В отечественной суицидологии СX в рамках аутоагрессивного поведения $[10,11]$. Обобщающий термин СХ поведения - сознательные и неосознанные причинение себе несмертельного вреда телесному или психическому здоровью как разрушение или изменение любых тканей тела (самопорезы, самоотравление), независимо от мотивов или намерения умереть связано с риском психических расстройств, суици-
How to comprehend the splendor and fullness of youth, if all forces are spent on fighting mistakes, with the false dogmas of parents and a long line of ancestors? Is it the main earthly destiny of youth - to rebel, destroy, kill? Is it for this purpose the youth is given to sacrifice it? And what about youthful dreams?! Are they always considered silly quirks of age? Dreams are springs and buds of imagination. Try to stifle or distort youthful dreams, and you will destroy their creator. Where there was no true youth, true maturity is impossible.... G. Miller. "Time for killers".

The "Generation Snowflake" was the name given to those born in the countries of the golden billion after the 1990s. The biggest round dances of snowflakes are in the high school of prestigious schools. Imagine carefree well-fed snowflakes who hate violence (as they think); safety (including emotional) is above all for them; they are acutely sensitive, suspicious and impressionable; not accustomed to deprivation, hard work, rude treatment; intolerant of opponents; they see history as a series of crimes, which they renounce (from world literature too); they are convinced of their uniqueness and value themselves highly; they have limited imagination; when their ideas do not coincide with real life, they are under severe stress; they willingly share their intimate experiences, are feminist-minded, politically correct left-wing children, vegetarians; do not tolerate silence and loneliness.

Historical perspective of $\mathrm{SH}$.

Non-fatal and deliberate forms of $\mathrm{SH}$ are considered as attempts at suicide, regardless of the intention to die voluntarily [8].

In addition to the discussion about motivation, the hypostasis of $\mathrm{SH}$ has led to confusion.

To teach words does not mean to give "knowledge of things". Shakespeare W. "The Storm".

Nothing is more hostile to precision of judgment than lack of discrimination. E. Burke

The terms "parasuicide" [9], "self-injury", $\mathrm{SH}$, "non-fatal deliberate self-harm" are used for SH behavior that does not lead to death regardless of the intention to commit suicide. However, parasuicide is often followed by "true" SB. According to the definition of WHO (1982), parasuicide and a suicide attempt (incomplete suicide) are synonymous.

In the national suicidology $\mathrm{SH}$ is studied in the framework of autoaggressive behavior [10, 11]. The generalizing term for $\mathrm{SH}$ behavior is conscious and unconscious infliction of nonfatal harm to bodily or mental health to oneself as destruction or alteration of any body tissues (self-cutting, self-poisoning), regardless of the motives or intention to die; $\mathrm{SH}$ is associated with the risk of mental disorders, suicidal behavior (SB) and other adverse consequences $[12,13,14]$. 
дального поведения (СП) и иных неблагоприятных последствий $[12,13,14]$.

Широкое определение CX включает несуицидальные СX (нСX) и суицидальные попытки [15].

Возможно, этиологически и функционально отличные друг от друга при существенном перехлесте [15] и поведенческое намерение в отношении самоубийства изменчиво $[16,17]$.

Большинство совершающих СX не стремятся покончить с собой, и «попытка самоубийства» не применима к широкому спектру намерений, выражаемых сходным поведением [18].

Различают СХ поведение прямое, когда телесные повреждения служат предполагаемой цели и непрямое, или косвенное [17].

Обзор сосредоточен на прямом СX, а именно, нCX, но полезно обсудить косвенные формы CX и рассмотреть, как они связаны с прямым.

Косвеннное СХ поведение [цит. по 19].

Клинический интерес восходит к 30-м годам XX века. Косвенный СX включает действия, увеличивающие вероятность негативных последствий и / или уменьшающие шанс достижения позитивных [20], а потому определено, вслед психоаналитику К. Меннингеру, полагавшему «членовредительство» (selfmutilation) проявлением ослабленного желания смерти, частичного, или смягченного суицида [21] как «затяжное», «медленное» самоубийство.

Монтгомери Клифт (25 лет), один из первых секссимволов, после вечеринки врезался в столб. Сломал нос и челюсть, скула осталась парализованной. Пристрастился к болеутоляющим и спиртному. CX актёра названо «самым долгим суицидом в истории Голливуда» (умер через 20 лет).

Рембо был живым самоубийцей ... Из соображений приличия он мог бы покончить счёты с жизнью в девятнадцать лет, но нет, он все тянул и тянул и, по прихоти, растратив жизнь впустую, сделал нас свидетелями живой смерти... В том, что он превратил успех в такое горькое поражение, и заключалось его торжество. Требовалась дьявольская смелость (пусть и неосознанная), дабы наглядно доказать это. Г. Миллер «Время убийц»

«Король Голливуда» К. Гейбл, не оправившийся годами после гибели жены, искал смерти лётчиком, затем пил и носился на мотоцикле меж съёмок, заявляя, что «не ищет смерти, а просто не хочет жить» ${ }^{1}$.

Осознанное намерение умереть и немедленный личный вред не служат ведущими мотиваторами поведения; физический вред и / или боль отставлены от самого поведения, но негативные последствия проявлены в краткосрочной и долгосрочной перспективах [18]. Налицо компромисс, когда некий риск травмы / вреда (возможно, отставленного и необязательного) известен и приемлем как побочный эффект при балансе с желаемыми преимуществами сиюминутного
The broad definition of SH includes nonsuicidal $\mathrm{SH}(\mathrm{nSH})$ and suicidal attempts [15].

Possibly they are etiologically and functionally distinct from each other with significant overlap [15], even though behavioral intention to commit suicide is variable $[16,17]$.

Most of those who commit SH do not seek to commit suicide, and an "attempted suicide" does not apply to the wide range of intentions expressed by similar behavior [18].

There is direct SH behavior when bodily injury serves the intended purpose and nondirect or indirect $\mathrm{SH}$ [17].

The review focuses on direct SH, particularly $\mathrm{nSH}$, but it is useful to discuss indirect forms of $\mathrm{SH}$ and how they relate to direct $\mathrm{SH}$.

Indirect SH behavior [cit. to 19].

Clinical interest dates back to the 1930s. Indirect $\mathrm{SH}$ includes actions that increase the likelihood of negative consequences and / or reduce the chance of achieving positive ones [20], and therefore it is determined, following the psychoanalyst K. Menninger, who believed "self-mutilation" to be a manifestation of a weakened desire for death, partial, or mitigated suicide [21] as a "protracted", "slow" suicide.

Montgomery Clift (25), one of the first sex symbols, crashed into a pole after a party. $\mathrm{He}$ broke his nose and jaw, and the cheekbone remained paralyzed. He got addicted to painkillers and alcohol. Actor's SH was called "the longest suicide in the history of Hollywood" (died 20 years later).

Rimbaud was a living killer of self ... For reasons of decency, he could have committed suicide at nineteen, but no, he protracted and protracted and, on a whim, having wasted his life in vain, he made us witnesses of a living death ... In a way he turned his success into such a bitter defeat there was his triumph. It took devilish courage (albeit unconscious) in order to clearly prove this. G. Miller. "Killers' time".

"The King of Hollywood" K. Gable, who wasn't able to recover after his wife's death for years, sought death as a pilot, then drank and rushed around on a motorcycle between filming, declaring that "he is not looking for death, but simply does not want to live".

Conscious intention to die and immediate personal harm are not the leading motivators of behavior; physical harm and / or pain are removed from the behavior itself, but negative consequences are manifested both immediately, and in the long run [18]. There is a give-andtake with some risk of injury / harm (possibly delayed and unnecessary) being known and acceptable as a side effect but overbalanced with the desired benefits of momentary pleasure [17].

... Striving for happiness, a person simultaneously, involuntarily, by force, strives for unhap-

\footnotetext{
${ }^{1}$ Созвучно: бывает, что не хочется жить, но это ещё не значит, что хочется не жить. Ежи Лец..
} 


\section{удовольствия [17].}

... стремясь к счастью - человек одновременно, невольно, вынужденно, стремится и к несчастью. Ну - побочный эффект, нежелательная, но обязательная нагрузка в магазине жизненных благ. Если так - то все просто: Счастье обжорства - перевешивает несчастье ожирения, склероза, уродливой фигуры, преждевременных болезней и смерти. Счастье пьянства - сильнее несчастья нищеты. Счастье подвига - сильнее несчастья увечья. М. Веллер «Всё о жизни: Стремление к счастью»

Косвенное $C X$ представляет спектр намеренных или неосознанных действий, вредных для физического или психического здоровья без стремления к добровольной смерти, как употребление психоактивных веществ (ПАВ); рискованное, делинквентное поведение; анозогнозия опасной телесной болезни [22, 23].

Среди склонных к самоубийству [цит. по 19] рядом с искателями смерти с СП игроки со смертью, осознанно стремящиеся к неоправданному риску для жизни; одобряющие смерть, осознанно заявляющие о желании смерти без активных действий (видимо, антивитальное настроение).

У самой вершины западного пика лежит иссохший мерзлый труп леопарда. Что понадобилось леопарду на такой высоте, никто объяснить не может. Э. Хемингуэй «Снега Килиманджаро»

В субботу вечером словил кайф, напился и улёгся на рельсы в ожидании одиннадцатичасового поезда, положив два больших куска цемента себе на грудь и ноги, и поезд подъезжал всё ближе и ближе. И он проехал по соседним рельсам рядом со мной вместо того, чтобы проехать по мне. К. Кобейн.

Рискованное (для здоровья) поведение - тип вредоносного поведения: вместо желаемого поведения (подросток) осознает высокую вероятность небольшого («а вдруг пронесет») вреда как злоупотребление ПАВ, совместное использование игл, незащищенный секс и промискуитет, участвует в приятном занятии без ожидания вреда (прыжки с тарзанкой).

Каждое следующее поколение находит свой способ сломать себе шею. Новое приключение. Не говоря уж о старом, испытанном - войне. И. Шоу «Вершина холма»

O, эти старания, жажда секундной славы! Мир был мал, человека четыре, пять ... и в этом космосе клокотало наше вожделение: доказать. Нежная, сочащаяся, алая плоть детства ... Нас всех поразило безумие. Показалось, что ходить и даже бегать по барьеру невероятно легко... Тогда это началось: испытывать волю. Ю. Трифонов. «Дом на Набережной».

Как и при нСХ, поведение может причинить физический вред и боль, но опасения подавлены, и первые не служат самоцелью поведения.

Врачи запретили Бродскому курить. Это его очень тяготило: выпить утром чашку кофе и не закурить?! Тогда и просыпаться незачем! С. Довлатов «Соло на ундервуде»

Хотя - жить можно. Что херово

- курить подталкивает бес.

Не знаю, кто там Гончарова,

но сигарета - мой Дантес. piness. Well - this is a side effect, an undesirable but obligatory load in the store of life. If so, then everything is simple: The happiness of gluttony outweighs the misery of obesity, sclerosis, an ugly figure, premature illness and death. The happiness of drunkenness is stronger than the misery of poverty. The happiness of feat is stronger than the unhappiness of injury.

\section{Weller. "Everything About Life: The Pur-} suit of Happiness"

Indirect $\mathrm{SH}$ represents a range of intentional or unconscious actions harmful to physical or mental health without a desire for voluntary death, like the use of psychoactive substances (PAS); risky, delinquent behavior; anosognosia of a dangerous bodily illness [22, 23].

At the very top of the western peak lies the withered, frozen corpse of a leopard. Nobody can explain what the leopard needed at such a height. E. Hemingway. The Snows of Kilimanjaro.

On a Saturday night I got high and drunk, and went to the rails waiting for the eleven o'clock train. I put two large pieces of cement on my chest and legs, while the train was coming closer and closer. And it ran the adjacent rails next to me instead of running over me. K. Cobain.

Risky (for health) behavior is a type of harmful behavior: instead of the desired behavior adolescent realizes the high probability of small ("what if it doesn't happen") harm such as substance abuse, sharing needles, unprotected sex and promiscuity, or participates in a pleasant activity without expecting the harm (bungee jumping).

Each next generation finds its own way to break its neck. A new adventure. Not to mention the old, tried-out one - a real war. I. Shaw. "The Top of the Hill".

Oh, these efforts, the thirst for a second of glory! The world was small, there were four, five people ... and in this realm our desire was bubbling: to prove. Delicate, oozing, scarlet flesh of childhood ... We were all struck by madness. It seemed that walking and even running along the barrier was incredibly easy ... Then it began: to try out the will. Yu. Trifonov. "The House on the Embankment".

As with $\mathrm{nSH}$, behavior can cause physical harm and pain, but fears are suppressed, and the former do not serve as an end in itself for the behavior.

Doctors forbade Brodsky to smoke. This weighed heavily on him: to drink a cup of coffee in the morning without smoking?! Then there is no need to wake up! S. Dovlatov. "Solo on an Underwood".

Although - you can tolerate living. The demon

that pushes to quit smoking is a shit.

I don't know who this Goncharova is, but a cigarette is my d'Anthes.

I. Brodsky (three heart attacks and three packs of cigarettes a day)

However, smoking, drinking, Internet ad- 


\section{И. Бродский (три инфаркта и три пачки сигарет в день)}

Однако курение, пьянство, зависимость от Сети, и непреднамеренные травмы) проявлены физическими (диарея, лихорадка, кашель и рвота) и психическими нарушениями [24].

Переживание опасности использовано (экстремалом) для самоуспокоения ... когда игры со смертью выглядят как средство борьбы с разрушительной депрессией ... Травматофилический процесс подобен токсикомании: оба способствуют регрессии в поведении и оба успокаивают...Соотношение между поиском страха и страдания и инстинктом самосохранения позволяет говорить о «перверсии» последнего. «Неонужда», вопреки инстинкту самосохранения обнаруживается как зависимость [25].

Доморощенный эгоцентрик, турист-экстремал «наказан» инфарктом. Н. Плотников «Маршрут Эдуарда Райнеpa»

Во второй 1/2 XVIII в юные девы, чрезмерно увлечённые «ампирной модой» в туниках, смоченных водой, смело выходили на холод и заболевали чахоткой. Journal de mode в 1802 г., рекомендовал посетить Монмартское кладбище и посчитать жертв «нагой моды».

«Доброкачественный мазохизм», по аналогии с «доброкачественной агрессией» Э. Фромма [26], желание боли с осознанием, что она не вызовет серьёзных повреждений.

Комплекс деструктивных страстей (садомазохизм) Фромм называет синдромом ненависти к жизни, за которой возможная хроническая депрессия.

Риск одного приключения дороже тысячи дней благополучия и комфорта. П. Коэльо «Вероника решает умереть»

Под сенью подсознательного «символического суицида» Э. Дюркгейма, отличающего намерение отказа от жизни и знания о возможных, но необаятельных последствиях вредоносного поведения ${ }^{1}$, малолетние «адские водители» (автоциды - серая зона суицидальной статистики), перенимающих печальнй опыт на дорогах: «каждый водит, как живет».

Дед - внуку: руферов, зацеперов, трейсеров / паркурщиков... в моё время звали ласково - «дебилами». Из глубин Сети.

\section{Для разрядки любезного читателя:}

Руки-ноги перегрызены, весь в шрамах, но не может жить без риска - с плеткой опять в клетку к диким зверям. Всем он известен: Куклачёв. Из глубин Сети.

В аддиктивном поведении обострены, по Э. Берну, голод сенсорной стимуляции, признания

Мальчики вместе играли, шалили, и вот на четвертый или на пятый день гощения на станции состоялось между глупою молодёжью одно преневозможное пари в два рубля, именно: Коля, почти изо всех младший, а потому несколько презираемый старшими, из самолюбия или из бес- diction, and unintentional trauma are manifested though physical (diarrhea, fever, coughing and vomiting) and mental disorders [24].

The experience of danger is used (by an extreme fan) for self-soothingness ... when games with death look like a means of fighting destructive depression ... The traumatophilic process is similar to substance abuse: both contribute to regression in behavior and both calm one down... The relationship between the search for fear and suffering and the instinct of selfpreservation allows us to speak of the "perversion" of the latter. The "Neo-need" unlike the instinct of self-preservation is revealed as dependence [25].

The homegrown egocentric, extreme tourist was "punished" with a heart attack. N. Plotnikov. "Eduard Rayner's route".

In the second half of the 18th century, young maidens, overly keen on "empire fashion" boldly went out into the cold in tunics moistened with water and fell ill with phthisis. Journal de mode in 1802, recommended visiting the Montmarthe Cemetery to count the victims of "nude fashion".

"Benign masochism", by analogy with E. Fromm's "benign aggression" [26], is the desire for pain with the knowledge that it will not cause serious damage.

Fromm calls the complex of destructive passions (sadomasochism) the syndrome of hatred of life, followed by possible chronic depression.

The risk of one adventure is more valuable than a thousand days of well-being and comfort. $P$. Coelho. "Veronica decides to die"

Under the shadow of E. Durkheim's subconscious "symbolic suicide", which distinguishes the intention to renounce life and knowledge about the possible, but not charming consequences of harmful behavior, young "hellish drivers" (autocides are a gray zone of suicidal statistics), adopting sad experience on the roads: "Everyone drives the same way he lives."

A grandfather says to his grandson: In my time there was one word to describe roofers, hookers, tracers / parkourists affectionately - "morons". From the depth of the Network.

To ease the kind reader:

His hands and feet are gnawed, he is all covered with scars, but he cannot live without risk so he enters again a cage of wild animals with a whip. Everyone knows him: Kuklachev. From the depths of the Network.

In addictive behavior, according to $\mathrm{E}$. Bern, lies the hunger for sensory stimulation and recognition.

The boys played together, made fun, and on the fourth or fifth day of staying at the station, one almost impossible bet of two rubles took place between the stupid youth, namely: Kolya, almost

Картина жизни: кассиру - привычно-ерническое: «мне ту синюю пачечку с раком легких». 
пардонной отваги, предложил, что он, ночью, когда придёт одиннадцатичасовой поезд, ляжет между рельсами ничком и пролежит недвижимо, пока поезд пронесется над ним на всех парах. Правда, сделано было предварительное изучение, из которого оказалось, что действительно можно так протянуться и сплющиться вдоль между рельсами, что поезд конечно пронесется и не заденет лежащего, но, однако же каково пролежать! Коля стоял твердо, что пролежит. Над ним сначала смеялись, звали лгунишкой, фанфароном, но тем пуще его подзадорили. Главное, эти пятнадцатилетние слишком уж задирали пред ним нос и сперва даже не хотели считать его товарищем, как "маленького", что было уже нестерпимо обидно ... В надлежащий час Коля лёг между рельсами. Пятеро остальных, державших пари, с замиранием сердца, а наконец в страхе и с раскаянием, ждали внизу насыпи подле дороги в кустах. Наконец загремел вдали поезд, снявшийся со станции. Засверкали из тьмы два красные фонаря, загрохотало приближающееся чудовище. "Беги, беги долой с рельсов!" - закричали Коле из кустов умиравшие от страха мальчишки, но было уже поздно: поезд наскакал и промчался мимо. Мальчишки бросились к Коле: он лежал недвижимо. Они стали его теребить, начали подымать. Он вдруг поднялся и молча сошёл с насыпи. Сойдя вниз, он объявил, что нарочно лежал как без чувств, чтоб их испугать, но правда была в том, что он и в самом деле лишился чувств, как и признался потом сам, уже долго спустя, своей маме. Таким образом, слава "отчаянного" за ним укрепилась навеки. Воротился он домой на станцию бледный как полотно. На другой день заболел слегка нервною лихорадкой, но духом был ужасно весел, рад и доволен. $Ф$. Достоевский «Братья Карамазовы»

По Шкловскому, гениальный Е. Поливанов, прочитав «Братьев Карамазовых», на спор положил руку под поезд.

Сравните с прерванным суицидом (Андреев Л. «Весной») в декорациях железной дороги:

«Вот тут я и лягу»,- подумал Павел, вглядываясь в невидимые рельсы. Он уже целую неделю ходил сюда и присматривался, и тут нравилось ему, так как всё - и воздух и могильная тишина говорили о смерти и приближали к ней. Когда он так сидел, тяжело, всем телом, и стены выемки охватывали его, ему казалось, что он уже наполовину умер и нужно сделать немного, чтобы умереть совсем. Каждую весну, вот уже три года, он думал о смерти, а в эту весну решил, что умереть пора. Он ни в кого не был влюблен, у него не было никакого горя, и ему очень хотелось жить, но все в мире казалось ему ненужным, бессмысленным и оттого противным до отвращения, до брезгливых судорог в лице.

Рискованное поведение подростков способствует хроническим телесным и психическим расстройствам в старшем возрасте [27].

Термин СX использован при описании разнообразного поведения с несмертельным исходом, в котором человек преднамеренно инициирует поступки, как самопорез или употребление ПАВ с намерением (с формальным осознанием пагубных последствий) причинить себе вред [28].

Вероятные негативные последствия опосредованы дополнительными факторами, а связь поведения и the youngest of all, and therefore somewhat despised by the elders, out of pride or out of shameless courage, suggested that he, at night, when the eleven o'clock train arrives, would lie face down between the rails and lie motionless while the train runs above him at full steam. Though a preliminary study was made, from which it turned out that it is really possible to stretch out and got oneself flat between the rails so that the train will of course sweep and not touch the lying one, but, nevertheless, what is it like to lie! Kolya stood firm that he would lie down. At first, they laughed at him, they called him a liar, a fanfaron, but that made him even more provoked. The main thing is that these fifteen-year-olds looked down at him and at first did not even want to consider him a friend, because he was a "little one", which is already intolerably offensive ... At the proper hour, Kolya lay down between the rails. The five others, betting, with bated breath, and finally in fear and remorse, were waiting at the bottom of the rail road in the bushes. Finally, a train pulled out of the station rang in the distance. Two red lanterns flashed out of the darkness, and the approaching monster rumbled. "Run, run off the rails!" - the boys dying of fear shouted to Kolya from the bushes, but it was too late: the train galloped and rushed past. The boys rushed to Kolya: he was lying motionless. They began to pull at him, began to lift him. He suddenly got up and silently walked off the hill. Going down, he announced that he was deliberately lying as if he were unconscious in order to frighten them, but the truth was that he indeed lost his senses, as he himself later admitted to his mother, a long time later. Thus, the glory of the "desperate" one was his forever. He returned home to the station, pale as a sheet. The next day he fell ill with a slightly nervous fever, but was terribly cheerful, glad and contented in spirit. $F$. Dostoevsky. The Brothers Karamazov.

According to Shklovsky, the brilliant E. Polivanov having read "The Brothers Karamazov" put his hand under the train for a bet.

Compare with the interrupted suicide (L. Andreev "Spring") in the scenery of the railway:

"This is where I'll lie down," thought Pavel peering into the invisible rails. For a whole week he had been walking here and looking closely, and he liked it here, because everything - both the air and the silence of the grave spoke of death and brought him closer to it. When he sat like that, heavily, with his whole body, and the walls of the pit surrounded him, it seemed that he was already half-dead and that only a little effort is needed to die completely. Every spring, for three years now, he thought about death, and this spring he decided that it was time to die. He was not in love with anyone, he did not have any grief, and he really wanted to live, but everything in the world seemed unnecessary, meaningless and therefore obnoxious to disgust, to squeamish convulsions in his face.

Risk behavior in adolescents contributes to chronic physical and mental disorders in older age [27].

The term $\mathrm{SH}$ is used to describe a variety 
вреда весьма вероятна: включает не только участие в ситуациях высокого риска для жизни и здоровья, но и «бездействие» (намеренное уклонение от лечения хронических, потенциально опасных для жизни, болезней), пренебрежение своим здоровьем и безопасностью [29], часто и - окружающих.

В типологии суицидов, по E. Schneidman, иниц̧иаторы смерти: неизлечимо больные, отказывающиеся от жизнеспасающей, но не душеподьемной помощи. По Дюркгейму, суицид - и результат осознанного «отрицательного поступка» жертвы.

Тесса (16 лет) бросает мучительное неэффективное лечение лейкоза и выполняет список небезобидных желаний «всё попробовать». Её кредо: если тебе плохо, сделай так, чтобы было плохо и всем остальным. Дж. Даунхэм «Сейчас самое время»

Пандемия корона-вируса высветила новыестарые проявления рискованного поведения [30, 31].

На другом полюсе эгоцентрического поведения «нерациональный» подвиг, альтруистическая, по Э. Дюркгейму, жертва - делу общественному (так называемая позитивная девиация).

Лучше я, ночной порою

Погибая на седле,

Буду счастлив под землею,

Чем несчастен на земле...

M. Сваетлов «В разведке»

Итак, СX - любое намеренное самоповреждение независимо от мотивации [32].

Несуицидальные самоповреждения (нСX) - прямое непосредственное и преднамеренное, нередко повторное, повреждение (разрушение) тканей своего тела социально неприемлемое (не соответствующее культурным ожиданиям или нормам) без намерения самоубийства $[17,33,34]$.

Мысли об участии в СХ поведении рассматривается его предвестником.

Поступки человека - лучшие переводчики его мыслей. Дж. Локк.

Первая научная статья о СX в России... (может быть аспиранты глянут С.С. Корсакова) за рубежом: в Германии в середине XIX века [цит. по 35], но текущие научные дебаты вокруг нСХ с 1960-х гг. с «синдрома запястья» (не путать с туннельным синдромом).

нСХ означает прямое и преднамеренное причинение вреда (боль, рана) сразу после такого поведения [36] без намерения смерти. нСХ есть действие (подростка), преднамеренно причиняющего себе физическую боль и/или или поверхностный урон телу или принимая какое-либо вредоносное вещество (передозировка лекарства). Термин «нСХ» применим для СХ без суицидальных намерений с целью желаемых перемен посредством фактических или ожидаемых физических последствий.

Прямые и косвенные формы СX часто со- of non-fatal behavior, in which a person deliberately initiates actions, such as self-cutting or the use of surfactants with the intention (with formal awareness of the harmful consequences) to harm themselves [28].

Possible negative consequences are mediated by additional factors, and the relationship between behavior and harm is very likely: it includes not only participation in situations of high risk to life and health, but also "inaction" (deliberate avoidance of treatment of chronic, potentially life-threatening diseases), neglect of one's own health and safety [29] and often - of those around.

Tessa (16) gives up the painful ineffective treatment of leukemia and fulfills a list of not harmless desires "to try everything." Her motto is if you feel bad, make it bad for everyone else. $J$. Downham. "Before I die".

The corona-virus pandemic has highlighted new-old manifestations of risky behavior $[30,31]$

At the other pole of egocentric behavior, there is an "irrational" feat, altruistic, according to E. Durkheim, a sacrifice to a public cause (the so-called positive deviation).

It is better for me to die at night

While I am on the saddle

So that I would be happy under the ground

Rather than unhappy on earth ... M. Svaetlov. "On an assignment"

So, SH is any intentional self-harm, regardless of motivation [32].

Non-suicidal self-harm $(\mathrm{nSH})$ is direct, immediate and deliberate, often repeated, damage (destruction) of tissues of one's body that is socially unacceptable (not corresponding to cultural expectations or norms) without the intention of suicide [17, 33, 34].

Thoughts about engaging in $\mathrm{SH}$ behavior are seen as its precursor.

A person's actions are the best translators of his thoughts. J. Locke.

The first scientific article on SH in Russia (maybe graduate students will check out S. S. Korsakov) was published abroad, in Germany in the middle of the $19^{\text {th }}$ century [cit. to 35], but the current scientific debate around $\mathrm{nSC}$ has been going on since the 1960s starting with "the wrist syndrome" (not to be confused with carpal tunnel syndrome).

$\mathrm{nSH}$ means direct and deliberate harm (pain, injury) immediately after such behavior [36] without the intention of death. $\mathrm{nSH}$ is an act (by a teenager) deliberately causing themselves physical pain and / or superficial damage to the body or taking any harmful substance (drug overdose). The term "nSH" is applicable to SH without suicidal intentions with the goal of desired change through actual or anticipated physical consequences

Direct and indirect forms of SH often ac- 
путствуют друг другу. Например, 1/4 совершающих нСX сообщают о расстройстве пищевого поведения (нервной анорексии или булимии) и наоборот [цит. по 18]. Ограничивающие себя в еде сообщают о большем желании причинить себе боль в долгосрочной перспективе, чем переедающие или использующие иные компенсаторные формы поведения. То есть при «косвенном» СX прослежены непосредственно вредные намерения, общие с нСX.

У выбравших прямые или косвенные формы СX много общих черт, но и ключевые различия. При сравнении вовлечённых в нСX и косвенные формы $\mathrm{CX}$ (беспорядочная еда, злоупотребление ПАВ, «токсические» отношения, безрассудное поведение), с занимающимися только косвенными формами СX первые сообщали о более высоком уровне самокритики и повышенной склонности к СП [18].

Распространённость нСХ в широких пределах в зависимости от географических и экономических факторов, социо-демографических характеристик выборок, возрастной подгруппы и, в непоследнюю очередь, критериев оценки. СХ совершают 7,5-46,5\% (в среднем каждый пятый) подросток в мире против 4-23\% взрослых. Частота СХ европейских подростков не менее 10-13\%; девушки втрое чаще сообщают о $\mathrm{CX}$. Сходны данные о нCX, хотя подразумевается исключение суицидальных попыток, составляющих часть СX (парасуицидов). нСX, часто повторные, особо характерны у подростков $[13,35,37]$.

В неклинических выборках нСX (данные международных опросов учащихся) у 16-22\% подростков $[37,38,39]$, возможно, 25-35\% в отдельных европейских рандомизированных школьных выборках [35] против 2,5-5\% (4\%) взрослых [39].

В российской выборке из почти 650 старших школьников и студентов 13-23 лет 10-14\% сообщили о CX (самопорезах), а 3\% - о «частых», причём у дев чаще CX, а у юношей они более тяжелые [40]. В ходе скрининга 600 московских школьников 7-11-х классов $17 \%$ указали на нСХ, а почти $1 / 2(46 \%)$ - неоднократно [41].

нCX ( $\geq 1$ эпизода) в течение жизни у $25-35 \%$ подростков против 2,5-5\% (4\%) взрослых [35, 37] при средних показателях в школьных выборках 14,5-17 (826)\% [38, 39] со сходными показателями у дев и юношей [38], но большими, чем у молодых (13\%) и старших $(5,5 \%)$ в общем населении [39]. Так, почти $20 \%$ старших школьников в целом (у $1 / 4$ дев) в репрезентативной выборке США $\geq 1$ нСХ за последний год [42]. Каждый десятый (12\%) школьник сообщает о повторных нСX (= 5 эпизодов в коротенькой пока жизни) [37]. Возможно, данные завышены.

В клинических выборках подростков и молодых 37-50\% [43] против 4-21\% взрослых [44].

Начало нСX приурочено к раннему (12-14 лет) company each other. For example, $1 / 4$ of those committing $\mathrm{nSH}$ report an eating disorder (anorexia nervosa or bulimia nervosa) and vice versa [cit. by 18]. Those who restrict themselves on food report a greater desire to hurt themselves in the long term than those who overeat or use other compensatory behaviors. That is, in the case of "indirect" SH, the same harmful intentions are directly traced as with $\mathrm{nSH}$.

Those who chose direct or indirect forms of SH have not only many similarities, but also key differences. When comparing those involved in $\mathrm{nSH}$ and indirect forms of SH (disordered eating, substance abuse, "toxic" relationships, reckless behavior), with those involved in only indirect forms of $\mathrm{SH}$, the first report a higher level of self-criticism and an increased propensity to SB [18].

The prevalence of $\mathrm{nSH}$ varies widely on geographic and economic factors, sociodemographic characteristics of the samples, age subgroups and, last but not least, assessment criteria. SH are committed by $7.5-46.5 \%$ (on average every fifth) teenagers in the world versus $4-23 \%$ of adults. The frequency of $\mathrm{SH}$ among European adolescents is no less than 10$13 \%$; girls are three times more likely to report $\mathrm{SH}$. The data on $\mathrm{nSH}$ is similar, even though suicidal attempts that are part of the SH (parasuicides) are excluded. $\mathrm{nSH}$, often repeated, are especially typical in adolescents [13, 35, 37].

In non-clinical samples of $\mathrm{nSH}$ (data from international student surveys) there are involved $16-22 \%$ of adolescents $[37,38,39]$, possibly 25 $35 \%$ in selected European randomized school samples [35] versus $2.5-5 \%$ (4\%) adults [39].

In a Russian sample of almost 650 senior schoolchildren and students aged 13-23, 10$14 \%$ reported SH (self-cuts), with 3\% "frequent" actions; girls tend to report SH more often, while boys tend to report more severe forms [40]. During the screening of 600 Moscow schoolchildren in grades $7-11,17 \%$ indicated $\mathrm{nSH}$, and almost $1 / 2(46 \%)$ did that more than once [41].

$\mathrm{nSH}$ ( $\geq 1$ episode) during life is reported by $25-35 \%$ of adolescents versus 2.5-5\% (4\%) adults [35, 37] with average indicators in school samples of 14.5-17 (8-26)\% [ 38, 39] with similar indicators in girls and boys [38], which are higher than in young $(13 \%)$ and older $(5.5 \%)$ samples in the general population [39]. Thus, almost $20 \%$ of senior schoolchildren as a whole ( $1 / 4$ girls) in a representative sample of the USA reported $\geq 1 \mathrm{nSH}$ over the last year [42]. Every tenth (12\%) schoolchild reports repeated $\mathrm{nSH}$ (= 5 episodes in a short life so far) [37]. The data may be overstated.

In clinical samples there are $37-50 \%$ of adolescents and young adults [43] versus 4-21\% of adults [44].

The onset of nSH is confined to early (12- 
подростковому возрасту [43, 45], но описаны с 4-х лет [46, 47], причем и СП с некими допущениями, возможно с 5 лет (Амбрумова) и входят в официальную статистику.

На «пиковые» показатели нСХ подростков 15-16 лет указывают длительные наблюдения [48], при существенных различиях риска СП в раннем и старшем подростковом возрастах и росте риска иных видов дисфункционального поведения (как злоупотребление ПАВ) по мере взросления.

Мета-анализ 72 баз данных [45] указал пожизненную распространенность СХ у каждого пятого (17\%) из почти 600000 подростков 12-18 лет при росте за 25 лет (1990-2015 гг.)

Частота CX подростков 12-17 лет представлена моделью айсберга [49].

«Вершина» - смертельные (суициды, не всегда явные) исходы редки; «тело» составляют СХ - ведут к медицинской помощи. «Подводная часть» - CX в общей возрастной и клинической субпопуляциях скрыта $^{1}$ и недооценена. В 12-14 лет на каждую жертву суицида-мальчика приходится 100 госпитализированных после СX и 3000 сообщивших о СX; и в 15-17 лет $-1: 120: 800$, соответственно. У дев тех же возрастов соотношения $1: 1200: 22000$ и 1: $900: 6400$, соответственно.

Давайте поговорим о том, почему вы хотели покончить с собой. - Я не хотела покончить с собой! Сюзанна, четыре дня назад вы приняли упаковку аспирина и запили его бутылкой водки. - У меня болела голова ... С. Кейсен «Прерванная жизнь» $60 \%[50]$.

Пожизненная распространённость нСX 17-

Естественное течение и развитие нСX неясно, но нСХ идут на спад по мере прощания с молодостью.

нСХ повторяются и становится хроническим, причем 1/4 его совершающих сообщают о 11-50 эпизодах. Частота повторных нСX неизменна в 1980-1990-х гг. и после 2000 г. $16 \%$ за год при уровне госпитализаций $14 \%$, а по самоотчетам - 22\% [51].

При развитии произвольно-экспериментальных манипуляций в гиперкомпенсаторное поведение, у большинства подростков, психиатрических пациентов, нСХ в типовых ситуациях становится в течение 3-6 месяцев самоцелью, долговременными, повторяющимися стереотипно, «привычными».

Признаки аддиктивного поведения (известного и при СП) в снижении порога нСХ, смены «безобидных» форм аутоагрессии (щипки, царапины, интенсивное расчёсывание) самопорезами; учащении нCX в одном эпизоде при укорочении пауз от недель до дней - часов.

И хотя я резала себя понапрасну, и это мне совсем не
14 years) adolescence [43, 45], but there are records of its development from 4 years of age $[46,47]$, and SB is included in the official statistics with certain assumptions from 5 years of age (Ambrumova).

Long-term observations [48] indicate that the peak of nSH rates falls on 15-16 years of age with significant differences in risk in early and older adolescence and an increase in the risk of dysfunctional behavior (like the use of psychoactive substances) as they get older.

A meta-analysis of 72 data bases during 25 years (1990-2015) [45] indicates an increase in the lifetime prevalence of $\mathrm{SH}$ in one in five $(17 \%)$ of almost 600,000 adolescents aged 12 18.

The frequency of SH in 12-17-aged adolescents is represented by the iceberg model [49].

The "top" (suicides, not always obvious) entails fatal outcomes that are rare; The "body" is made up of $\mathrm{SH}$ which leads to medical assistance. The "underwater part" is comprised of SH in the general age and clinical subpopulations - it is hidden and underestimated. At the age of 12-14, for every male suicide attempter there are 100 hospitalized males due to $\mathrm{SH}$ and 3000 of those who reported $\mathrm{SH}$; and at the age of 15-17 the ratio goes 1: 120 : 800 , respectively. For girls of the same ages, the ratios are 1 : 1200: 22,000 and 1: $900: 6400$, respectively.

Let's talk about why you wanted to commit suicide. - I didn't want to commit suicide! "Suzanne, four days ago you took a pack of aspirin and washed it down with a bottle of vodka. - My head ached ... S. Keisen. "The Interrupted Life"

The lifetime prevalence of $\mathrm{nSH}$ is $17-60 \%$ [50].

The natural course and development of $\mathrm{nSH}$ is unclear, but $\mathrm{nSH}$ is declining as we grow older.

$\mathrm{nSH}$ is repeated and becomes chronic, with $1 / 4$ of those who commit it reporting 11-50 episodes. The frequency of repeated nSH will remain the same during 1980s-1990s and after 2000 s it stays at $16 \%$ per year with hospitalizations staying at $14 \%$ and with self-reports indicating $22 \%$ [51].

With the development of voluntaryexperimental manipulations into hypercompensatory behavior, within 3-6 months nSH in typical situations becomes long-term, repetitive stereotypically, "habitual" for adolescents and psychiatric in-patients.

Signs of addictive behavior (also known in SB) manifest themselves in lowering the threshold of nSH, substituting the "harmless" forms of autoaggression (pinching, scratching, intensive combing) with self-cuts; increasing the number of $\mathrm{nSH}$ along with shortening pauses from

${ }^{1}$ Sub rosa (лат.) - «под розой», то есть, «тайно», «по секрету». 
помогало, а только создавало для меня новые проблемы, в этих действиях всё-таки был смысл и человеческое желание, от которых не осталось и следа в холодных словах лектора о том, что пациент уже «не пытается испробовать новые методы», и в его таблицах с графами «частота», «диагноз» и «повторяемость». Я надолго задумалась о том, что же тут осталось от жизни, её страданий, страхов, от тоски, отчаяния, страха смерти и страха жизни и жгучего кровавокрасного упорства. Однако для лекции, пожалуй, эта тема была бы слишком сложна. Статистика, как правило, бывает гораздо проще и схематичнее. Арнхильд Лаувенг «Завтра я всегда бывала львом»

Без эмоционального облегчения самопроизвольный обрыв эпизодов CX за несколько месяцев. Отсутствие позитивного эмоционального эффекта / ослабления отрицательных эмоциональных состояний, замена СX иными компенсаторно-регулирующими альтернативами играют ведущую роль в спонтанном обрыве нСX.

нСХ не ограничены подростковым возрастом и молодостью, СХ возможно в течение всей жизни (пожилые - «серая зона») как продолжение подросткового или впервые выявленное, более - в рамках более очевидной психопатологии.

Гайдар резался. Лезвием безопасной бритвы. У него отнимали одно лезвие, но стоило отвернуться, и он уже резался другим. Попросился в уборную, заперся, не отвечает. Взломали дверь, а он опять режется, где только раздобыл лезвие? Увезли в бессознательном состоянии, все полы в квартире были залиты свернувшейся в крупные сгустки кровью... Я думал, он не выживет. При этом не похоже было, что он стремился покончить с собой; он не пытался нанести себе смертельную рану, просто устраивал своего рода «шахсей-вахсей». Позже, уже в Москве, мне случалось видеть его в одних трусах. Вся грудь и руки ниже плеч были сплошь - один к одному - покрыты огромными шрамами. Ясно было, он резался не один раз... Б. Закс «Воспоминания о Гайдаре»

Россиянин П. известен перформансами - самоистязаниями как средством общественно-политического высказывания: зашивал себе рот (по примеру уголовников), прибил мошонку гвоздем на площади; на заборе НМИЦ ПН им. ВП Сербского, отрезал себе мочку уха в знак протеста против карательной психиатрии. Публичные СX завершают судебно-психиатрические экспертизы, признающие его вменяемым (в России), но страдающим ПРЛ (Франция).

Гендерный аспект СХ. Женщины более подвержены CX в клинических выборках и в общем населении [46]. Женский пол связан с более частыми психопатологическими проблемами [52], особенно интернализующими, и они связаны с более высоким риском более серьёзных форм СХ, как СП [53, 54]. нCX в анамнезе чаще у женщин [46]. Возможно, женский пол сам по себе - фактор риска нСX [55, 56], стрессогенных беспокойства и депрессии [37, 57], более частых нСХ у дев подростков (отношение шансов 1,5) [56], чем у сверстников-юношей, особо в клинических выборках [58]. Риск повтора нСХ выше weeks to days and hours.

And although I cut myself in vain, and it did not help me at all, and it only created new problems for me, these actions still had meaning and human desire, from which not a trace remained in the cold words of the lecturer that the patient already "Doesn't try out new methods", and in his tables with columns "frequency", "diagnosis" and "repeatability". I thought for a long time about what was left of life, its suffering, fears, longing, despair, fear of death and fear of life and burning blood-red stubbornness. However, for a lecture, perhaps, this topic would be too complex. Statistics, as it happens, are much simpler and more schematic. Arnhild Lauveng. "Tomorrow I've always been a lion."

Without the emotional relief, a spontaneous interruption of $\mathrm{SH}$ episodes becomes possible in a few months. The absence of a positive emotional effect / weakening of negative emotional states, the replacement of $\mathrm{SH}$ and compensatory-regulating alternatives play a leading role in the spontaneous termination of the $\mathrm{nSH}$.

$\mathrm{nSH}$ is not limited to adolescence and youth, perhaps it goes on throughout life (the elderly are the "gray zone") being diagnosed during adolescence for the first time and, which is more probable, being part of a more obvious psychopathology.

Gaidar cut himself. With a safety razor blade. One blade was taken away from him, but as soon as you turned away, he already cut himself with another one. He asked to go to the restroom, locked himself, did not respond. They broke down the door, and he was cut again, how did he get the blade? They took him away unconscious, all the floors in the apartment were covered with blood coagulated into large clots ... I thought he would not survive. It didn't seem like he was trying to commit suicide; he did not try to inflict a mortal wound on himself, he simply arranged a kind of "shahsei-wahsey". Later, already in Moscow, I happened to see him in only his underpants. The entire chest and arms below the shoulders were completely - one by one - covered with huge scars. It was clear that he had cut himself more than once ... B. Sachs. "Memories of Gaidar".

The Russian P. is known for his self-torture performances as a means of social and political expression: he sewed up his mouth (following the example of criminals), nailed his scrotum to the square; cut off his earlobe on the fence of the National Medical Research Center of A.P. Serbskiy to protest against punitive psychiatry. These public $\mathrm{SH}$ acts are followed by forensic psychiatric examinations, recognizing him as sane (in Russia), but suffering from BPD (in France).

Gender aspect of $\mathrm{SH}$. Women are more susceptible to $\mathrm{SH}$ in clinical samples and in the general population [46]. Female gender is associated with more frequent psychopathological problems [52], especially internalizing problems, and these are associated with a higher risk 
у страдающих расстройствами личности дев, когда первый СХ требовал больничного лечения.

Триггерами нСX служат стрессогенные конфликты, обычно с близкими, в большинстве случаев их объективная тяжесть не соответствует субъективной значимости для подростка, позволяя предположить их кататимно-психогенный характер, обусловленный типичной подростковой дефензивностью и/или депрессией. Большинство подростков с многократными СX за последние 12 месяцев столкнулись с «смертью / болезнью близкого», «проблемами и конфликтами в семье» [40].

Личностная предиспозиция, наряду с импульсивностью и аффективной нестабильностью, отчасти представлена классическими чертами аддиктивной личности, по B. Segal (1989): сниженная переносимость трудностей повседневной жизни при хорошей переносимости кризисных ситуаций; скрытый комплекс неполноценности, сочетающийся с внешне проявляемым превосходством; внешняя социабельность со страхом перед стойкими эмоциональными контактами; стремлением говорить неправду; обвинять невиновных; уходить от ответственности в принятии решений; стереотипность, повторяемость поведения (как нСХ или употребление ПАВ); зависимость; тревожность; уязвимость в сфере эмоциональной регуляции; личности с низким уровнем эмоциональной компетентности, трудностями понимания собственных эмоций и выражения.

Факторы риска нСХ. Не известна единственная (простая) причина нСХ или СП.

Вот как странно устроен человек, и какие тонкие грани отделяют нас от благополучия или гибели. М. Шелли «Франкенштейн, или Современный Прометей»

Биопсихосоциальный подход рассматривает СX как динамическое единство биологических, психологических, культурных, общественных факторов реализации СX поведения (включают продолжительность и частоту реализации поведенческой стратегии, тяжесть последствия). Эти переменные конструируют особенность восприятия и реакцию человека на своё поведение и отношение к этому поведению окружающих.

Различают факторы риска и корреляции [59].

Корреляции связаны с конкретным результатом, но специфика ассоциации неоднозначна. Если нарушение регуляции эмоций сосуществует с нСX, первое - коррелят второго, если предшествует нСХ и отличит низкую от высокой вероятности нСX, то - фактор риска. Причинные факторы риска важны для прогнозирования, развития гипотез и целей лечения.

Большинство исследований нСХ коррелятов (перекрестных ассоциаций с нСX), но развиваются анализы длительного прогноза нСХ [60]. Большинство коррелятов и факторов риска СХ предсказывают многие формы неадаптивного поведения, включая нСХ. of more serious forms of SH, such as SB [53, 54]. History of $\mathrm{nSH}$ is more common in women [46]. Perhaps the female sex itself is a risk factor for $\mathrm{nSH}[55,56]$, stress-generating anxiety and depression $[37,57]$, and more frequent $\mathrm{nSH}$ in adolescent girls $(\mathrm{OR}=1,5)$ [56] than in male peers, especially in clinical samples [58]. The risk of recurrence of $\mathrm{nSH}$ is higher in girls with personality disorders when the first $\mathrm{SH}$ required hospital treatment.

$\mathrm{nSH}$ are triggered by stressful conflicts, usually with loved ones; in most cases, their objective severity does not correspond with the subjective significance for the adolescent, suggesting their catatim-psychogenic nature, caused by typical adolescent defensivity and / or depression. The majority of adolescents with multiple SH over the past 12 months have faced "death / illness of a loved one", "problems and conflicts in the family" [40].

Personal predisposition, along with impulsiveness and affective instability, is partly represented by the classic traits of an addictive personality, according to B. Segal (1989): reduced tolerance of the difficulties of everyday life with good tolerance of crisis situations; latent inferiority complex, combined with externally manifested superiority; external sociability with fear of persistent emotional contacts; the desire to tell a lie; accuse the innocent; avoid responsibility in decision making; stereotypicality, repetition of behavior (like $\mathrm{nSH}$ or the use of surfactants); addiction; anxiety; vulnerability in the sphere of emotional regulation; individuals with a low level of emotional competence, difficulties in understanding their own emotions and expression.

Risk factors for $\mathrm{nSH}$. The only (simple) cause of nSH or SB is unknown.

This is how strangely a person is arranged, and what fine lines separate us from prosperity or death. M Shelley. "Frankenstein, or Modern Prometheus".

The biopsychosocial approach considers $\mathrm{SH}$ as a dynamic unity of biological, psychological, cultural, social factors in the implementation of $\mathrm{SH}$ behavior (include the duration and frequency of implementation of the behavioral strategy, the severity of the consequences). These variables construct the peculiarity of a person's perception and reaction to their behavior and the attitude of others to this behavior.

There are risk factors and correlations [59].

The correlations are associated with a specific result, but the specificity of the association is ambiguous. If dysregulation of emotions coexists with $\mathrm{nSH}$, the first is a correlate of the second, if it precedes $\mathrm{nSH}$ and distinguishes low from high probability $\mathrm{nSH}$, then it is a risk fac- 
нСХ включают повышенный уровень негативных / неприятных мыслей и чувств; плохие навыки общения; плохие способности решать проблемы; жестокое обращение, плохое обращение, враждебность и критицизм в детстве; дисфункциональную реакцию на стресс; потребность самонаказания; моделирование поведения (например, сверстники, интернет) [61].

Представление и устранение стимулов, как считается, усиливающих СX, могут уменьшить и увеличить это поведение в ожидаемом направлении.

${ }_{H} C X$ в анамнезе - сильнейший (отношение шансов $\approx 6)$ прогностический фактор повтора нСX [60], в сравнении безнадежности (отношение шансов> 3); остальных групп факторов, $(\leq 2)$, ограниченно клинически применимых. Предыдущее поведение служит одним из самых сильных предикторов поведения будущего. С первого эпизода повышен риск рецидива нСX [62]. Аналогия с СП и депрессивными фазами (киндлинг).

Исходный уровень нСХ наиболее значим как предиктор СП, психических расстройств [37], формируемого ПРЛ и расстройств приёма пищи.

Неблагоприятные жизненные события.

Жизнь - ящик, полный колющих и режущих инструментов. Всякий час мы калечим себе руки до крови. Жюль Ренар

Эмоционально неустойчивые подростки сталкиваются с давлением сверстников, одиночеством и конфликтами с близкими или другими значимыми для них лицами. На первом этапе (младшие подростки) переходят из начальных классов в средние, а на втором (старшие) - из школы в колледжи ВУЗы, «взрослую трудовую (семейную) жизнь». Переходы расшатывают систему социальной поддержки и чувство идентичности, создают стрессогенные факторы. У подростка без хороших навыков преодоления трудностей и надежной сети поддержки, дистрессы могут стать подавляющими. Возможно, сомневаются в личной идентификации и/или сексуальной ориентации; социально изолированы, прикованные к компьютеру (как хикимори).

Жестокое обращение в детстве: распространённость $10 \%$ применительно к сексуальному (6\% мальчиков, $13 \%$ девочек), $23 \%$ - применительно к физическому и $29 \%$ - психическому и эмоциональному насилию [63] с долгосрочными последствиями.

Показана связь нСX с жестоким обращением (эмоциональным, сексуальным и / или физическим насилием) и безнадзорностью в детстве $[64,65]$. Некоторые подростки с нСX были и остаются безнадзорны в формально полных семьях или фактические сироты.

Семьи подростков с нСX показывают высокий уровень враждебности и критики, указывая проблемы приёма слабых речевых сигналов. Если родители отвечают только на некоторые стимулы и оставляют без tor. Causal risk factors are important for prognosis, hypothesis development, and treatment goals.

Most studies concentrate on nSH correlates (cross associations with $\mathrm{nSH}$ ), but there are some analysis developing that study long-term prediction of $\mathrm{nSH}$ [60]. Most correlates and risk factors for SH predict many forms of maladaptive behavior, including $\mathrm{nSH}$.

$\mathrm{nSH}$ include increased levels of negative / unpleasant thoughts and feelings; poor communication skills; poor problem-solving ability; childhood abuse, mistreatment, hostility and criticism; dysfunctional stress response; the need for self-punishment; modeling of behavior (for example, peers, the Internet) [61].

Presentation and elimination of stimuli is believed to be enhancing SH can decrease and increase this behavior in the expected direction.

The history of $n S H$ is the strongest $(\mathrm{OR} \approx 6)$ predictor of repeated $\mathrm{nSH}$ [60], in comparison to hopelessness (OR> 3); other groups of factors, $(\leq 2)$, are of limited clinical applicability. Past behavior is one of the strongest predictors of future behavior. Starting with the first episode, the risk of nSH recurrence increases [62]. There is an analogy with $\mathrm{SB}$ and depressive phases (kindling).

The baseline $\mathrm{nSH}$ level is the most significant predictor of SB, mental disorders [37], formed by BPD and eating disorders.

Adverse life events.

Life is a box full of piercing and cutting tools. Every hour we maim our hands to the point of bleeding. Jules Renard.

Emotionally unstable adolescents face peer pressure, loneliness, and conflict with loved ones or other important people. At the first stage they (younger adolescents) move from primary to middle classes, and at the second stage they (older adolescents) move from school to colleges, universities, "adult working (family) life." Transitions shatter the social support system and sense of identity and create stressors. For a teenager without good coping skills and a reliable network of support, distress can become overwhelming. They may have doubts about their personal identity and / or sexual orientation; socially isolated, chained to a computer (like hikimori).

Childhood abuse prevalence reaches $10 \%$ for sexual abuse (6\% for boys, $13 \%$ for girls), $23 \%$ for physical abuse, and 29\% for mental and emotional abuse [63] with long-term consequences.

It has been shown that $\mathrm{nSH}$ is associated with abuse (emotional, sexual and / or physical abuse) and neglect in childhood [64, 65]. Some adolescents with nSH were and become neglected even if their families are formally com- 
внимания другие, в восприятии ребёнка формируется своеобразная селективная реальность. Родители могут игнорировать аффективные и кинестетические сигналы, реагируя только на переживание ребёнком боли [66].

Родительские факторы связаны с нСХ детей [67]: предписания «Не живи» (ребёнок как экзистенциальная тягота) в основе аутоагрессии, $и$ «Не думай» (делай), подталкивают к неадаптивной копингстратегии рискованного поведения, СП и нСX [68], конфликты и холодность в семье, предоставленность детей самим себе.

Психиатрическая коморбидность. Половина психических расстройств «родом из детства». Каждый десятый-пятый ( $15 \%)$ 4-17 лет страдает психическими расстройствами, часто не диагностируемыми и не леченными должным образом [69, 70, 71].

нСX связаны с широким рядом психических расстройств [40, 72, 73]: посттравматическим стрессовым расстройством (ПТСР), СДВГ, диссоциальными, истерическими, нарциссическими расстройствами личности (кластер В ДСМ-4 и 5).

нСХ включен симптомом ПРЛ с тех пор, как расстройства личности вошли в DSM 40 лет назад. Эмоциональная дисрегуляция - ключевая особенность многих психических расстройств как парадигмальное ПРЛ и / или нСХ $[47,74]$.

Поперечные и длительные исследования показали более высокие уровни аффективных (депрессивных, биполярных) и тревожных расстройств, расстройств пищевого поведения совершивших $\mathrm{HCX}$ [60].

Конечно, глупо обвинять мир в том, что мне скверно, да я и не обвиняю, но невольно общие выводы окрашиваются в чёрный цвет, или в серый, это верней. Это всё очень банально, что я говорю. М. Цветаева (15 лет), письмо, 27 августа 1908 г.

Депрессии препятствуют совладанию со стрессогенными ситуациями, регуляцию эмоции; больные заужены на негативных аспектах жизни, особо уязвимы к социальной изоляции, дискриминации, стигматизации (ограничивающих готовность к помощи), замыкая порочный круг, затрудняют учёбу, питают рискованное поведение, влекут телесные недуги.

При психосоматических расстройствах и/или нСХ тело служит средством преодоления психической боли через физические расстройства (головная боль, боль в животе, тошнота, проблемы сна, головокружение, сыпь). Страдания усугублены незнанием близких, как поддержать и управлять подростком с $\mathrm{CX}$, поиск помощи отложен, пока чадо не испытает трудности, прямо не связанные с нСX [12], как нарушения поведения, школьная неуспешность.

Риск повышен при психиатрической коморбидности (как при сочетании с употреблением ПАВ, средством самолечения депрессии) и неадекватном plete or even become actual orphans.

Families of adolescents with nSH show a high level of hostility and criticism, indicating problems with receiving weak speech signals. If parents respond only to some stimuli and ignore others, a kind of selective reality is formed in the child's perception. Parents can ignore affective and kinesthetic signals, reacting only to the child's experience of pain [66].

Parental factors are associated with the nSH of children [67] include: the "Do not live" message (the child as an existential burden) as the basis of autoaggression, and "Do not think" message ("Do not do") as a push for a nonadaptive coping strategy of risky behavior, SB and nSH [ 68], conflicts and coldness in the family, children being left to themselves.

Psychiatric comorbidity. Half of mental disorders come from childhood. Every tenth to fifth $(\approx 15 \%)$ of $4-17$ year olds suffers from mental disorders, often not diagnosed and not properly treated $[69,70,71]$.

$\mathrm{nSH}$ is associated with a wide range of mental disorders [40, 72, 73] such as posttraumatic stress disorder (PTSD), ADHD, dissocial, hysterical, narcissistic personality disorders (cluster B in DSM-4 and 5).

$\mathrm{nSH}$ has been included as a symptom of BPD since personality disorders entered the DSM 40 years ago. Emotional dysregulation is a key feature of many mental disorders such as paradigmatic BPD and / or nSH $[47,74]$.

Cross-sectional and long-term studies have shown higher levels of affective (depressive, bipolar) and anxiety disorders, eating disorders who have committed nSH [60].

Of course, it's stupid to blame the world for being bad for me, and I don't blame, but involuntarily general conclusions turn black, or gray, that's more accurate. This is all very commonplace, what I'm saying. M. Tsvetaeva (15 y. o.), a letter, August 27, 1908

Depression interferes with coping with stressful situations, the regulation of emotions; patients are narrowed in the negative aspects of life, especially vulnerable to social isolation, discrimination, stigmatization (limiting the willingness to help), closing a vicious circle, impede their studies, eating risky behavior, and entail bodily ailments.

In psychosomatic disorders and / or $\mathrm{nSH}$, the body serves as a means of coping with mental pain through physical disorders (headache, abdominal pain, nausea, sleep problems, dizziness, rash). Suffering is aggravated by the lack of knowledge of loved ones how to support and manage a teenager with $\mathrm{SH}$; the search for help is postponed until the child experiences difficulties not directly related to nSH [12], such as behavioral disorders, school failure.

The risk is increased with psychiatric 
лечении, приравненном к отсутствию профессиональной помощи. Не более трети подростков даже с клинической депрессией или тревогой обращаются за профессиональной помощью. Почти $90 \%$ подростков с нCX соответствуют критериям оси I DSM-IV, включая экстернализирующие (63\%), интернализирующие (52\%) расстройства, употребление ПАВ $(60 \%)$, и оси II ДСМ личностных расстройств (67\%) [36], что значительно более, чем полагалось ранее: около $1 \frac{1}{2}$ подростков с нСX не соответствуют критериям «больших» психических расстройств [75].

Большинство психических расстройств подростков субсиндромально (атипично) представлены, и нСX становится их маркером.

В очередном опросе $\mathrm{BO}^{1}$ (до пандемии COVID19) почти 230 тыс. школьников 45 стран Европы и Канады - каждый четвертый сообщил о нервном напряжении раздражительности или нарушениях сна не реже раза в неделю; почти 30\% 15-летних дев и вдвое меньше юношей сетовали на «плохое настроение» чаще раза в неделю; каждый 10-й подросток к 15 годам ( $9 \%$ дев и $16 \%$ юношей) употребляют спиртное не реже раза в неделю.

Психическое благополучие подростков в 2014-18 гг. ухудшилось и ухудшается по мере взросления. Все более подростков едва справляются со школьной нагрузкой. Чем старше школьники и чем выше нагрузка, тем неприязненнее их отношение к школе и учителям. С удовольствием ходят в школу менее трети подростков. В особенно уязвимом положении социально незащищённые подростки, как представители меньшинств и мигрантов.

Запугивание (буллинг) служит решающим социальным фактором риска. Большие поперечные и продольные исследования показали связь самооценок опыта издевательств в детстве и раннем подростковом возрасте и нСХ подростков. В двух длительных исследованиях отношение шансов для СП и нСХ 1,6-3 [76].

Согласно гипотезе социальной сигнализации [36], нСХ проявлено при неспособности более слабых сигналов (беседа) достичь желаемого социального результата. Подростки усиливают социальный сигнал (криком), переходят от словесных к физическим формам Подросток пытается игнорировать издевательства сверстников, затем переходит к просьбам «отстать от него» (говорить $\rightarrow$ кричать), затем к физическим формам общения, как угрожающий мрачный готический стиль одежды и, наконец, $\mathrm{HCX}$ выступает comorbidity (like when combined with the use of psychoactive substances, a self-medication for depression) and inadequate treatment, which is equivalent to a lack of professional help. No more than a third of adolescents, even with clinical depression or anxiety, seek professional help. Almost $90 \%$ of adolescents with nSH meet the DSM-IV axis I criteria, including externalizing $(63 \%)$, internalizing (52\%) disorders, substance abuse $(60 \%)$, and axis II DSM personality disorders $(67 \%)$ [36], which is significantly more than was previously thought: about $1 / 2$ of adolescents with $\mathrm{nSH}$ do not meet the criteria for "major" mental disorders [75].

Most of the mental disorders in adolescents are subsyndromally (atypical) presented, and $\mathrm{nSH}$ becomes their marker.

In the next $\mathrm{WHO}^{1}$ survey (before the COVID-19 pandemic) of almost 230 thousand schoolchildren from 45 countries of Europe and Canada every fourth reported nervous tension, irritability or sleep disorders at least once a week; almost $30 \%$ of 15 -year-old girls and half as many young men complained of "bad mood" more often than once a week; every $10^{\text {th }}$ teenager by the age of 15 (9\% of girls and $16 \%$ of boys) drinks alcohol at least once a week

Mental well-being of adolescents in 201418 worsened and gets worse as they get older. More and more teenagers can barely cope with the school load. The older the students and the higher the workload, the more hostile their attitude towards school and teachers becomes. Less than a third of teenagers go to school with pleasure. Socially unprotected adolescents, such as representatives of minorities and migrants, find themselves in a particularly vulnerable position.

Bullying is a critical social risk factor. Large cross-sectional and longitudinal studies have shown an association between selfreported experiences of bullying in childhood and early adolescence and adolescent $\mathrm{nSH}$. In two long-term studies, the odds ratio for SB and $\mathrm{nSH}$ is 1.6-3 [76].

According to the hypothesis of social signaling [36], nSH is manifested in the inability of weaker signals (conversation) to achieve the desired social result. Teens amplify the social signal (by shouting), move from verbal to physical forms. The adolescent tries to ignore peer bullying, then moves on to requests to "leave him alone" (speak $\rightarrow$ shout), then to physical forms of communication, like a threatening dark

\footnotetext{
${ }^{1}$ Inchley J., Currie D., Budisavljevic S. и др., ред. В центре внимания здоровье и благополучие подростков. Результаты исследования «Поведение детей школьного возраста в отношении здоровья» (HBSC) 2017/2018 гг. в Европе и Канаде. Международный отчет. Том 1. Основные результаты. Копенгаген: Европейское региональное бюро ВОЗ, 2020.

Inchley J., Currie D., Budisavljevic S. et al., Ed. The focus is on adolescent health and well-being. Findings from the Health Behavior in School-aged Children (HBSC) Survey 2017/2018. in Europe and Canada. International report. Volume 1. Main results. Copenhagen: WHO Regional Office for Europe, 2020.
} 
проявлением силы и жизнестойкости. Процесс эскалации описан теорией принуждения (coercion theory), которой, объясняющей агрессивное и диссоциальное поведения.

«Социальное заражение»: Влияние референтной группы сверстников (реальной или виртуальной), чье мнение авторитетно и к которой подросток хочет принадлежать [77] через внутриличностные функции.

В ходе социального обучения [78] на решения подростка влияют наблюдения, сведения о поведении сверстников, значимых для него взрослых, как употребление ПАВ, рискованное поведение или СХ [36]. Иногда этому способствуют культура отношения к конфликтам в семье. Установки и концепции в отношении эмоций: запреты на выражение злости, обиды; отсутствие культуры обращения за помощью и эмоциональной поддержкой; запрет на проявление слабости.

Подросток с нСХ в больнице повышает риск подобных проявлений у других больных [79, 80]. Ситуация жёсткой соревновательности, ориентации на достижения в школе, превалирование в подростковой среде завышенных стандартов красоты, доступность сайтов, где подростки демонстрируют такие способы поведения.

Подростковый синдром гадкого утёнка превратил начинающую актрису Анжелику Д в панка-неформала - пурпурные волосы, чёрные одеяния, колющережущие «игрушки, шрамы и скобы на зубах («шоковая терапия, по Д).

СМИ (интернет). нСХ - горячая тема Сети $[81,82]$.

ВО3 отмечает негативное влияние на психическое здоровье подростков цифровых технологий. Более трети общаются с друзьями онлайн весь день. У $7 \%$ признаки «цифровой зависимости». Более $10 \%$ (особо девы) сообщают о кибертравле за последние два месяца [6]. Есть веб-сайты со списками предупреждающих знаков (поведенческих указателей того, что СП подростка высоко вероятно в ближайшие нескольких часов-дней (острый пресуицид, по А. Амбрумовой) [83].

Доска объявлений «Bodies Under Siege» («Тело в осаде», по названию культовой книги A. Favazza) вебсайта «Тайный позор» - поле общения склонных к CX.

СМИ (интернет) распространяет информацию о $\mathrm{CX}$ : с добрыми намерениями сообщения могут фактически способствовать распространению такого поведения. Освещение в СМИ более результат увеличения уровня CX, а не его причина. Самоотчёты подтверждают гипотезу социального обучения, так как большинство подростков сообщают, что изначально узнали об этом от друзей, сиблингов и СМИ [85].
Gothic style in clothing and, finally, $\mathrm{nSH}$ is a manifestation of strength and vitality. The escalation process is described by coercion theory, which explains aggressive and dissocial behavior.

"Social contamination": The influence of a peer reference group (real or virtual), whose opinion is authoritative and to which the adolescent wants to belong [77] goes through intrapersonal functions.

In the course of social learning [78], adolescent decisions are influenced by observations and information about the behavior retrieved from peers, adults significant for him, on things such as substance abuse, risky behavior or $\mathrm{SH}$ [36]. Sometimes this is facilitated by a culture of attitude towards conflicts in the family. Attitudes and concepts in relation to emotions: prohibitions on the expression of anger, resentment; lack of a culture of seeking help and emotional support; prohibition of weakness.

An adolescent with nSH in hospital increases the risk of similar manifestations in other patients $[79,80]$. They find themselves in the situation of tough competition, orientation towards achievement in school, the prevalence of inflated beauty standards in adolescents, the availability of sites where adolescents demonstrate such behaviors.

The adolescent ugly duckling syndrome turned the aspiring actress Angelica J. into an informal punk - purple hair, black robes, stabbing toys, scars and braces on the teeth ("shock therapy, according to J).

Mass media (internet). nSH is a hot topic on the Web $[81,82]$.

WHO notes the negative impact of digital technology on the mental health of adolescents. More than a third of them chat with friends online all day. 7\% have signs of "digital addiction". More than $10 \%$ (especially girls) report cyberbullying in the last two months [6]. There are websites with lists of warning signs (behavioral indicators that eenager's SB is highly likely in the next few hours-days (acute presuicide, according to A. Ambrumova) [83].

The message board "Bodies Under Siege" ("The body is under siege", after the name of the cult book by A. Favazza) of the "Secret Shame" website is a field of communication for those inclined to SH.

The media (internet) disseminates information about SH: with good intentions, messages can actually contribute to the spread of such behavior. Media covers more the result of an increase in SH level, rather than its reason. Selfreports support the social learning hypothesis, as most adolescents report that they initially learned about it from friends, siblings, and the media [85]. 
Факторы риска нСХ подростков [48, 57, 60]

Таблица 1 / Table 1

Risk factors for $\mathrm{nSH}$ in adolescents $[48,57,60]$

\begin{tabular}{|c|c|}
\hline $\begin{array}{c}\text { Группы факторов риска } \\
\text { Risk factors groups }\end{array}$ & $\begin{array}{l}\text { Факторы риска } \\
\text { Risk factors }\end{array}$ \\
\hline $\begin{array}{l}\text { Демографические и социальные } \\
\text { Demographic and social }\end{array}$ & $\begin{array}{l}\text { Женский пол, незанятость, беспризорность/ } \\
\text { Female gender, no occupation, no adult control }\end{array}$ \\
\hline $\begin{array}{l}\text { Жестокое обращение и } \\
\text { физическое насилие в детстве } \\
\text { Violence and cruel treatment } \\
\text { during childhood }\end{array}$ & $\begin{array}{l}\text { Физическое, эмоциональное, сексуальное насилие; безнадзорность. Вик- } \\
\text { тимизация сверстниками } \\
\text { Physical, emotional, sexual abuse; neglect. Peer victimization }\end{array}$ \\
\hline $\begin{array}{l}\text { Семейные } \\
\text { Family }\end{array}$ & $\begin{array}{l}\text { Психический дистресс родителя (родителей). Развод родителей Конфликт } \\
\text { с родителями } \\
\text { Mental distress of the parent (s). Divorce of parents Conflict with parents }\end{array}$ \\
\hline $\begin{array}{l}\text { Клинические } \\
\text { (психопатологические) } \\
\text { симптомы }\end{array}$ & $\begin{array}{l}\text { Проблемы здоровья. Актуальный психосоциальный дистресс. Низкие } \\
\text { стессоустойчивость / жизнестойкость. Безнадёжность, Низкая самооценка } \\
\text { и обостренная самокритика. Нарушения социальной когниции (малые } \\
\text { навыки решения типовых жизненных трудностей). Тревожное, депрессив- } \\
\text { ное расстройства; СдВГ, расстройства питания. Агрессия. Экстернализу- } \\
\text { ющие (агрессия, делинквентное поведение) и интернализующие (депрес- } \\
\text { сия, тревога) нарушения поведения. Расстройство пищевого поведения. } \\
\text { Проблемы регуляции аффекта (ПРЛ). Зависимость от ПАВ (чаще спиртно- } \\
\text { го) } \\
\text { Health problems. Current psychosocial distress. Low stress resistance / vitality. } \\
\text { Hopelessness, Low self-esteem and heightened self-criticism. Disorders of so- } \\
\text { cial cognition (small skills in solving typical life difficulties). Anxiety, depres- } \\
\text { sive disorders; ADHD, eating disorders. Aggression. Externalizing (aggression, } \\
\text { delinquent behavior) and internalizing (depression, anxiety) behavior disorders. } \\
\text { Eating disorder. Affect regulation problems (ARP). Surfactant addiction (more } \\
\text { often alcohol) }\end{array}$ \\
\hline $\begin{array}{l}\mathrm{HCX} \text { и СП } \\
\mathrm{nSH} \text { and } \mathrm{SB} \\
\end{array}$ & $\begin{array}{l}\text { нСХ и СП (мысли, попытки) в анамнезе. Пример нСХ сверстников } \\
\text { (приятелей) } \\
\text { History of nSH and SB (thoughts, attempts). Peer / friends nSH }\end{array}$ \\
\hline
\end{tabular}

Факторы риска СП подростков. Мета-анализ 50 лет исследований факторов риска СП отметил малый прогресс в точности прогноза СП: немного лучше, чем случайность» [84].

Систематические обзоры и мета-анализы выделяют пересекающиеся сходные факторы риска нСX [48, 55] и СП. Подростки, думающие о суициде, в 12 раз чаще, чем сверстники, не думающих об этом, пытаются совершить самоубийство к 30 годам, причём почти $90 \%$ подростков в течение 12 месяцев после начала суицидальных мыслей [85].

Попытка стандартизированной оценки риска ведёт к большому количеству ложно положительных результатов [86], так как выявленные факторы риска и предупреждающие знаки СП недостаточно чувствительны и конкретны, чтобы точно предсказать неизбежный риск самоубийства [87].

Хотя детальный обзор факторов риска СП выходит за рамки данного сообщения [см. подробнее 88], выявлен ряд изменяемых и неизменяемых, отдаленных и ближайших (как бессоница) факторов риска СП подростков. Не известно, какие комбинации факторов риска особо важны для прогноза СП [84].
Risk factors for $\mathrm{SB}$ in adolescents. A meta-analysis of 50 years of research on risk factors for SB noted little progress in predictive accuracy for SB: slightly better than a chance" [84].

Systematic reviews and meta-analyzes highlight overlapping similar risk factors for $\mathrm{nSH}[48,55]$ and SB. Teens who think about suicide are 12 times more likely than their peers who do not think about it to try to commit suicide by the age of 30 , and almost $90 \%$ of adolescents do that within 12 months after the start of suicidal thoughts [85].

An attempt of standardized risk assessment leads to a large number of false positives [86], since the identified risk factors and warning signs of SB are not sensitive and specific enough to accurately predict the imminent risk of suicide [87].

Although a detailed review of risk factors for SB is beyond the scope of this report [see. more details 88], a number of changeable and unchanged, distant and immediate (like insomnia) risk factors for adolescents SB were revealed. It is not known which combinations of risk factors are especially important for the 
Интегративная теоретическая модель нСХ [36] объединяет разнообразные факторы риска и описывает, как они могут привести к развитию и поддержанию СХ. Модель делает три основных предположения (см. рисунок). СХ часто повторяются, функционируя как немедленный эффективный метод регулирования аффективного / когнитивного опыта и / или желаемого воздействия на социальную среду. Риск СX увеличен за счёт факторов, предрасполагающих к нарушениям регуляции аффективного / когнитивного состояний или влияющих на социальную среду (например, физиологическая гиперактивность в ответ на стрессовые события, неразвитые вербальные и социальные навыки).

Человек не выбирает свою болезнь, но он выбирает стресс - и именно стресс выбирает болезнь. И. Ялом «Когда Ницше плакал»

В модели у подростков в силу внутриличностных и / или межличностных факторов уязвимости (неразвитых устных, коммуникативных и социальных навыков решения типовых проблем) ограничена способность совладать (переносить) со стрессогенными событиями, адаптивно регулировать эмоциональный / когнитивный или социальный опыт, что увеличивает вероятность $\mathrm{HCX}$.

Тому, кто живёт разумом, жизнь видится комедией. Для живущих чувствами или подвержен эмоциями, жизнь - трагедия. Г. Миллер «Время убийц»»

нСХ свидетельствует о слабой способности генерировать чёткий и эффективный словесный сигнал и эмоционально выразиться. Алекситимия (трудность определить и описать чувства) - общий признак $\mathrm{HCX}$ и соматизации: тело служит выражению и модуляции психологических и эмоциональных проблем [89].

Подростки обращаются за медпомощью до нСX или СП, жалуясь на физические, а не психологические тяготы. Способность наблюдать и регулировать эмоции важна для переживания негативного и позитивного аффектов. Трудность определения эмоций и ограничения эффективных стратегий их регуляции предсказывают СП [цит. по 88]. Ограниченные стратегии регуляции эмоций прогностически значимее трудностей идентификации эмоций.

Надо различать два вида мучений: физическое страдание и страдание моральное. Физическое страдание - испытание. Моральное страдание - выбор. Э.Э. Шмитт «Оскар и Розовая Дама»

Исследования животных и людей связывают ранние дистрессы с психопатологией, а характер нейробиологических эффектов (например, снижение активности в лобной коре) отражается на регуляции аффективных / когнитивных и социальных реакций на стресс $[36,85]$. Представление о «гене» CX нереалистично и неточно, учитывая сложную и многоопределяемую природу отношений генного поведения, так и СП. Хотя эффекты ранних стрессоров особо сильны при генети- prognosis of SB [84].

An integrative theoretical model of $\mathrm{nSH}$ [36] combines a variety of risk factors and describes how they can lead to the development and maintenance of SH. The model makes three main assumptions (see figure). SH is often repeated, functioning as an immediate effective method of regulating affective / cognitive experiences and / or desired social impact. The risk of $\mathrm{SH}$ is increased by factors predisposing to dysregulation of affective / cognitive states or affecting the social environment (for example, physiological hyperactivity in response to stressful events, undeveloped verbal and social skills).

A person does not choose his illness, but he chooses his stress - and it is the stress that chooses illness. I. Yalom. "When Nietzsche Wept"

In the model, adolescents, due to intrapersonal and / or interpersonal vulnerability factors (undeveloped oral, communication and social skills for solving typical problems), have limited ability to cope (endure) with stressful events, adaptively regulate emotional / cognitive or social experience, which increases the likelihood of $\mathrm{nSH}$.

To those who live by reason, life is seen as a comedy. For those who live by feelings or are subject to emotions, life is a tragedy. G. Miller. "Time of the killers"

$\mathrm{nSH}$ indicates a weak ability to generate a clear and effective verbal signal and to express emotionally. Alexithymia (difficulty in defining and describing feelings) is a common feature of $\mathrm{nSH}$ and somatization: the body serves to express and modulate psychological and emotional problems [89].

Adolescents seek medical help before the $\mathrm{nSH}$ or $\mathrm{SB}$, complaining of physical rather than psychological hardships. The ability to observe and regulate emotions is essential for experiencing negative and positive affects. The difficulty of identifying emotions and limiting effective strategies for their regulation predict SB [cit. by 88]. Limited strategies for regulating emotions are predictively more significant than difficulties in identifying emotions.

It is necessary to distinguish between two types of torment: physical suffering and moral suffering. Physical suffering is an ordeal. Moral suffering is a choice. E.E. Schmitt. Oscar and the Pink Lady

Animal and human studies have associated early distress with psychopathology, and the nature of neurobiological effects (eg, decreased activity in the frontal cortex) is reflected in the regulation of affective / cognitive and social responses to stress [36, 85]. The concept of the SH gene is unrealistic and inaccurate, given the complex and multifacet- 
ческой уязвимости, модерируемые эффекты смягчены социальной поддержкой. Помимо потенциального воздействия на внутриличностные уязвимости, ранние стрессоры, как взросление в враждебной / критической или жестокой среде, могут привести к трудностям общения или нарушению навыков решения социальных проблем, способствуя межличностным уязвимостям $[36,85]$.

Дистальные неспецифичные факторы (генетические, экологические и нейробиологические ранние дистрессы) уязвимости (чрезмерная эмоциональная реактивность, неразвитые социальные навыки) препятствуют когнитивному / поведенческому контролю, приводящему к стрессогенным аффективным / когнитивным и социальным ситуациям в основе неадаптивного совладания с внутриличностными и межличностными конфликтами, в свою очередь, увеличивающих риск психических (депрессивных) расстройств и опосредующих их связь с нСX $[36,85]$.

Общие факторы риска нCX увеличивают вероятность иных неадаптивных поведений для той же функции (стремление к наказанию, общению), например, употребление ПАВ, расстройства пищевого поведения, поэтому эти расстройства обычно сопряжены с HCX при выполнении упомянутых функций

Функциии (мотивации, ичели) н $\mathrm{CX}$ многоплановы и изменчивы.

Порок не в том, чтобы иметь желания, а в неумении подчинить их правилам разума; дело не в том, испытываете ли вы или не испытываете самих влечений, а в способности управлять ими и отказываться от них. Дж. Локк

Функииональный подход в общем предполагает, что некое поведение определено событиями, непосредственно предшествующими и следующими за ним.

нCX решает внутриличностные или межличностные проблемы посредством 1) желаемых изменений, как поддержка и внимание окружающих; 2) облегчения эмоциональной боли через физическую; разделения большой боли на «много маленьких» [40];

Одна боль всегда уменьшает другую. Наступите вы на хвост кошке, у которой болят зубы, и ей станет легче... А. Чехов «Тоска»

3) ослабления гнета или прекращения нежелательных поступков значимых других (ссоры, унижение, преследование, отчуждение); 5) уменьшения, отвлечения мучительных чувств и мыслей (гнев, обида, страх, беспокойство, отчаяние); 6) самоидентификации.

Большинство (подростков) сообщают о множественных функциях $\mathrm{HCX}$ [58]. HCX как «болезненная форма самопомощи» [90] временно (но споро) облегчает психосоциальный дистресс $[12,36,91]$ у $60-80 \%$ (подростков), но как стратегия ухудшает их положение [58].

Частый повод нСX - контроль невыносимых мыслей и чувств [45]. Так, заявляемая «причина» $\mathrm{HCX} 80 \%$ ed nature of the relationship between gene behavior and SP. Although the effects of early stressors are particularly strong in genetic vulnerability, the moderated effects are mitigated by social support. In addition to the potential impact on intrapersonal vulnerabilities, early stressors, such as growing up in hostile / critical or violent environments, can lead to communication difficulties or impaired social problem solving skills, contributing to interpersonal vulnerabilities $[36,85]$.

Distal nonspecific factors (genetic, environmental and neurobiological early distress) vulnerability (excessive emotional reactivity, undeveloped social skills) impede cognitive / behavioral control, leading to stressful affective / cognitive and social situations at the heart of maladaptive coping with intrapersonal and interpersonal conflicts in turn, increasing the risk of mental (depressive) disorders and mediating their relationship with $\mathrm{nSH}[36$, 85].

Common $\mathrm{nSH}$ risk factors increase the likelihood of other maladaptive behaviors for the same function (desire for punishment, communication), for example, substance use, eating disorders, therefore these disorders are usually associated with $\mathrm{nSH}$ when performing these functions.

The functions (motivations, goals) of the nSH are multifaceted and changeable.

The vice is not in having desires, but in the inability to subordinate them to the rules of reason; the point is not whether or not you experience the drives themselves, but the ability to control and abandon them. J. Locke.

The functional approach generally assumes that some behavior is determined by events immediately preceding and following it.

$\mathrm{nSH}$ solves intrapersonal or interpersonal problems through 1) desired changes, as support and attention of others; 2) relief of emotional pain through physical pain; dividing big pain into "many small ones" [40];

One pain always diminishes the other. You will step on the tail of a cat with a toothache and it will feel better ... A. Chekhov. "Anguish".

3) weakening the oppression or ending the unwanted actions of significant others (quarrels, humiliation, persecution, alienation); 5) reduction, distraction of painful feelings and thoughts (anger, resentment, fear, anxiety, despair); 6) self - identification.

Most (adolescents) report multiple functions of $\mathrm{nSH}$ [58]. $\mathrm{nSH}$ as a "painful form of self-help" [90] temporarily (but fast) alleviates psychosocial distress $[12,36,91]$ for $60-80 \%$ (adolescents), but as a strategy worsens their situation [58].

A frequent reason for $\mathrm{nSH}$ is the control 
школяров - «облегчение ужасного душевного состояния» [92]. Порочный круг нСX поведения выглядит так: негативные мысли (питаемые, например, психалгией) - дезадаптивное поведение (нСХ) - временное облегчение - долгосрочные негативные последствия (социальная изоляция и подтверждение убеждения «Я никому не нравлюсь») - возврат к негативным мыслям [40].

нСX - не всегда средство привлечения внимания (распространённый миф), но подросток пытаясь справиться со страданием, призывает окружающих «увидеть его боль» $[92,93]$.

Попытка самоидентификации («Страдаю, значит, существую») через маркировку кожи, «оболочку страдания» (татуировки, проколы) [94]. Знаки на коже и физическая боль становятся нарциссическими эмблемами. При (депрессивной) деперсонализации подросток стремится «почувствовать, что живой».

... наслаждалась собственными страданиями. Они доказывали, что я ещё существую. С. Кейсен «Прерванная жизнь»

«Я... резала себя, просто чтобы почувствовать боль. Это давало мне ощущение, что я реально существую, что я не сон». Арнхильд Лаувенг «Завтра я всегда бывала львом»

У меня не было стремления «нанести себе физическое повреждение», я стремилась порезать себя, потому что мне требовалось увидеть кровь. Часто, особенно в первый период моей болезни, я чувствовала себя какой-то ужасно пустой и далёкой, и серой, и мертвой. ... И в самый разгар своих страданий, среди серости и пустоты, я хотела получить вещественное доказательство того, что я жива, а не просто существую - во мне жизнь, как есть она в крови, огне, в духе, в капельках росы. Арнхильд Лаувенг «Завтра я всегда бывала львом»

нСX ограничивает поврежденно - диссоциированное тело, отчуждаемое и отчуждённое. Подростки теряют связность личности (personal cohesion), образ тела отчуждён от «Я» [95].

Тело не удовлетворяет, отсюда стремление заменить, изменить, перекроить форму или её детали. «Кромсание плоти» - послание тому, чьими глазами смотрит на себя подросток.

Я боялась, что у меня вместо крови течет овсяный кисель, и что в моем теле совсем не осталось живого тепла, что в нем нет ни искры жизни. Поэтому я расцарапывала себя и резалась, чтобы убедиться, что ... я не мертвый робот с овсяным киселем вместо крови. Арнхильд Лаувенг «Завтра я всегда бывала львом»

Сенсорная стимуляция (новые ощущения) отвлекают от «душевного онемения» и диссоциации) и расширяют опыт подростка.

Суть человека - как можно больше чувствовать и как можно больше делать, для чего приходится как можно больше думать. М. Веллер «Кассандра»

Искажения и нарушения образа тела изменчивы при нарушениях пищевого поведения, ПРЛ и депрессивных расстройствах, сопровождающих нСХ и/или of unbearable thoughts and feelings [45]. Thus, the stated "reason" for $\mathrm{nSH} 80 \%$ of schoolchildren is "relief from a terrible state of mind" [92]. The vicious circle of $\mathrm{nSH}$ behavior looks like this: negative thoughts (caused, for example, by psychhalgia) - maladaptive behavior $(\mathrm{nSH})$ - temporary relief long-term negative consequences (social isolation and confirmation of the belief "Nobody likes me") - return to negative thoughts [ 40].

It can also be viewed as an attempt of self-identification ("I suffer, therefore I exist") through the marking of the skin, "the shell of suffering" (tattoos, punctures) [94]. Skin marks and physical pain become narcissistic emblems. In case of (depressive) depersonalization, the adolescent attempts to "feel alive."

... Enjoying her own suffering. They proved that I still exist. C. Keysen. "The Interrupted Life".

"I... cut myself just to feel pain. It gave me the feeling that I really exist, that I am not a dream. " Arnhild Lauweng. "Tomorrow I've always been a lion."

I didn't have the urge to "physically harm myself," I was eager to cut myself because I needed to see the blood. Often, especially in the first period of my illness, I felt terribly empty and distant, and gray, and dead. ... And in the midst of my suffering, in the midst of dullness and emptiness, I wanted to receive material evidence that I am alive and not just exist - life is in me, as it is in blood, fire, spirit, dew drops. Arnhild Lauweng. "Tomorrow I've always been a lion."

$\mathrm{nSH}$ limits the damaged-dissociated body, alienated and alienated. Teenagers lose personal cohesion, the body image is alienated from the "I" [95].

The body does not satisfy, hence the desire to replace, change, reshape the form or its details. "Shredding of the flesh" is a message to the one through whose eyes a teenager views himself.

I was afraid that oatmeal jelly was flowing instead of blood, and that there was no living warmth in my body at all, that there was not a spark of life in it. So I scratched myself and cut myself to make sure that ... I'm not a dead robot with oatmeal for blood. Arnhild Lauweng. "Tomorrow I've always been a lion."

Sensory stimulation (new sensations) distracts from "mental numbness" and dissociation) and enhances the adolescent's experience.

The essence of a person is to feel as much as possible and do as much as possible, for which you have to think as much as possible. $M$. Weller. "Cassandra"

Body image distortions and disturbances are variable in eating disorders, BPD, and depressive disorders accompanying and / or of the same nature as $\mathrm{nSH}$. 
одной природы с ним.

Большинство теорий (точнее, гипотез) объясняют смысл нСХ дисфункциональной (дезадаптивной) стратегией совладания, регуляцией эмоциональной нестабильности $[60,96]$.

Анальгезии гипотеза [цит. по 36, 85]. Ожидаемые боль и отвращение (гемофобия?) повышают барьер СX подростков.

... чтобы одну сильную боль отвлечь другою... А. Чехов «От какой болезни умер Ирод?»

Однако нСХ, по самоописаниям, сопровождает слабая боль, или её отрицают. Болевая нечувствительность появляется до нСХ или при привыкании к физической боли при повторных СX.

... себя резали-то ножом - должно быть больно... Я посмотрел поближе - да, это были большие белые шрамы, их было много. «Поймете ли вы, - сказал Михаил Александрович. - Значит, что я любил женщину, она меня не любила ... Я страдал, но, когда резал себя, страдания уменьшались. $K$. Коровин «О М. Врубеле»

Обезболивание объяснено посттравматическим уровнем эндорфинов, приносящих и удовольствие (эйфорию), как употребление ПАВ; оба эффекта увеличивают вероятность рецидива нСХ. Сниженная болевая чувствительность при убеждении, что подросток заслуживает травмы, затрудняет привлечение его (её) к помощи.

«Вещество блаженства» анандамид (любители шоколада $^{1}$ его знают) связывается с каннабиноидными рецепторами мозга, блокирует болевые сигналы и вызывает приятное ощущение, похожее на действие марихуаны.

Самонаказания гипотеза [цит. по 36]. нСX служит средством наказания «ненавистного себя» [61] и / или самоуничижения. Самонаказанием объяснено 1/2 эпизодов нСХ; совершающие их отличаются обостренной самокритикой как фасада депрессии и/или раннего насилия, следствием критиканства окружающих (в семье), и подросток идёт на «самопожертвование» в виде $\mathrm{HCX}$.

...буду делать надрезы по всему телу, покрою всего себя татуировкой, хочу стать уродливым, как монгол; увидишь: улицы я оглашу своим воем. Я хочу обезуметь от ярости. Никогда не показывай мне драгоценностей: извиваясь, я поползу по ковру. Моё богатство? Я хочу, чтобы все оно было покрыто пятнами крови. Никогда не буду работать... $A$. Рембо "Сезон в аду»

Стратегия самоуничижения, применяемая, чтобы показать людям, к которым индивид должен проявлять любовь и уважение, что он, индивид, устал от них. Г. Френсис «Путешествие хирурга по телу человека»

Показательны самопорезы в виде слов «неудача» и «позор».

... резьба по коже давала чувство защищённости. Это доказательство. Ведь эти слова я всегда могла увидеть - они
Most of the theories (more precisely, hypotheses) explain the meaning of $\mathrm{nSH}$ as a dysfunctional (maladaptive) coping strategy, regulation of emotional instability $[60,96]$.

The analgesia hypothesis [cit. on 36, 85]. The anticipated pain and disgust (hemophobia?) increase the SH barrier in adolescents.

... to distract one severe pain with another ... A. Chekhov. "From what disease did Herod die?"

However, according to self-descriptions $\mathrm{nSH}$ is accompanied with mild pain, which can also be denied. Pain numbness appears before $\mathrm{nSH}$ or when you get used to physical pain with repeated $\mathrm{SH}$.

... they cut themselves with a knife - it must be painful ... I looked closer - yes, they were big white scars, there were many of them. "Will you understand," said Mikhail Alexandrovich. - It means that I loved the woman, she did not love me ... I suffered, but when I cut myself, the suffering lessened. K. Korovin "About M. Vrubel"

Pain relief is explained by the posttraumatic level of endorphins that bring pleasure (euphoria), like the use of surfactants; both effects increase the likelihood of recurrence of $\mathrm{nSH}$. Decreased sensitivity to pain in the belief that the adolescent deserves the injury makes it difficult to enlist him or her for help.

The "bliss substance" anandamide (chocolate lovers know it) combines with the brain's cannabinoid receptors, blocks pain signals and produces a pleasant sensation similar to that of marijuana.

Self-punishment hypothesis [cit. by 36]. $\mathrm{nSH}$ serves as a means of punishing "the hated self" [61] and / or self-deprecation. Selfpunishment explained 1/2 episodes of $\mathrm{nSH}$; those who do it are distinguished by exacerbated self-criticism as a facade of depression and / or early violence, as a result of criticism of others (in the family), and the teenager goes on "self-sacrifice" in the form of nSH.

... I will make cuts all over my body, cover myself with tattoos, I want to become ugly like a Mongol; you will see: I will announce the streets with my howl. I want to be mad with rage. Never show me jewelry: wriggling I'll crawl across the carpet. My wealth? I want it all covered in blood stains. I will never work ... A. Rimbaud. "A Season in Hell"

Self-deprecation strategy used to show people to whom the individual should show love and respect that he, the individual, is tired of them. G. Francis. "The surgeon's journey through the human body."

Self-cuts in the form of the words "failure" and "shame" are indicative.

... the carvings on the skin gave a sense of

\footnotetext{
${ }^{1}$ Шоколад - пропуск в новый мир. Мир, наполненный счастьем, улыбками и радужными красками. Мир, в котором возможно всё! Джованни Джакомо Казанова. Однако: Жизнь - как коробка шоколадных конфет. Никогда не знаешь, какая начинка попадётся". Форрест Гамп, к/ф США, 1994.
} 
не стираются. Это правда, приносящая мучительную боль, она зашифрована на мне, пусть и странным образом. Вы скажете, что идёте к врачу, и мне захочется вырезать у себя на руке: «неспокойно». Скажете, что влюбились, и я почувствую, как на груди уже зудит новое слово: «трагично». Не так уж мне хотелось вылечиться, но надоело прятаться и лихорадочно, как наркоман, искать на ногах свободное место, чтобы там нацарапать «зло» или «плач». Мне помогло слово «исчезните». Нетронутой осталась шея - прекрасное место, важное; я приберегла её для самого последнего слова. Г. Флинн. «Oстрые предметыл».

К негативным последствиям как охвостье нСХ отнесены неизбывные вина и стыд [91].

нСХ отличны по намерению, функции от СП. Так, нСХ используют как тактику выживания, для контроля (переключения) мыслей о самоубийстве и их реализации $[75,91]$.

На самом деле я хотела убить только часть себя - ту часть, которая хотела покончить с собой, заставляя меня все время размышлять об этом, превращая любое окно, любой поезд, любой предмет кухонной утвари в реквизиты на репетиции трагедии. Но поняла я это уже после того, как съела пятьдесят таблеток аспирина. С. Кейсен «Прерванная жизнь»

Я знаю, что такое хотеть умереть. Когда улыбка причиняет боль. Ты хочешь быть как все, но не можешь. Ты причиняешь себе физическую боль, пытаясь убить что-то в душе. С. Кейсен «Прерванная жизнь»

Неявного отношения / идентификации гипотеза [цит. по 36]. На выбор подростком поведения, выполняющего желаемую функцию, влияет неявное отношение к возможным опциям или идентификация с ними. Если кто-то намерен облегчить тревогу, вряд ли выпьет водки, коли не модно быть пьяницей, но разгонит мотоцикл до 250 км в час («я - байкер»). Подростки с опытом нСХ склонны его привычно повторить и идентифицируются с травмой. Особо, когда сверстники совершают СX (социальное моделирование), и поведение удовлетворяет предполагаемой функции (эмоциональная саморегуляция, социальная сигнализация).

Дело в том, что я - резчица. Есть резчики по камню, дереву и металлу, а я - особый случай. Я - резчица по коже. Своей коже. Она сама этого жаждет. Моя кожа вся исписана словами: «повар», «кекс», «котенок», «кудри», - как будто на ней учился писать первоклассник, вооруженный ножом. Иногда - только иногда - я смеюсь. Когда вылезаю из ванны и вскользь читаю слово «куколка», вырезанное сбоку на ноге. Или, пока надеваю свитер, вдруг вижу у себя на запястье: «вредно». Г. Флинн «Острые предметы»»

Теоретические модели нСХ предполагают, что поведение усиливается, если выгоды от СX перевешивают негативные последствия. Научно доказательные данные поддерживают аффект-регуляторную, самонаказания и антидиссоциативную модели нСХ.

Прагматическая гипотеза [цит. по 36, 85] самая экономная: подростки не освоили возможные навыки совладания с дистрессом, выбирая дезадаптивные (употребление ПАВ \pm нСХ), решаются на СX как на быст- security. This is a proof. After all, I could always see these words - they are not erased. This is true, excruciating pain, it is encrypted on me, albeit in a strange way. You will say that you are going to the doctor, and I will want to carve "restless" on my arm. Say you fell in love, and I will feel a new word itching on my chest: "tragic". I didn't really want to be cured, but I got tired of hiding and feverishly, like a drug addict, looking for a free place on my feet in order to scrawl "evil" or "crying" there. The word "disappear" helped me. The neck remained intact - a wonderful place, important; I saved it for the very last word. G. Flynn. "Sharp objects".

Inescapable guilt and shame are attributed to the negative consequences as the rump of the $\mathrm{nSH}$ [91].

$\mathrm{nSH}$ is different from $\mathrm{SB}$ in its intent and functions. Thus, $\mathrm{nSH}$ is used as a survival tactic, to control (switch) thoughts about suicide and their realization $[75,91]$.

In fact, I only wanted to kill a part of myself - the part that wanted to commit suicide, forcing me to think about it all the time, turning any window, any train, any piece of kitchen utensils into props for a tragedy rehearsal. But I realized this after eating fifty aspirin tablets. S. Keysen. "The Interrupted Life".

I know what it is like to want to die. When a smile hurts, You want to be like everyone else, but you can't. You are hurting yourself physically by trying to kill something in your soul. $C$. Keysen. "The Interrupted Life".

Implicit relationship / identification hypothesis [cit. by 36]. The adolescent's choice of behavior that performs the desired function is influenced by an implicit attitude towards possible options or identification with them. If someone intends to ease the anxiety, they are unlikely to drink vodka, since it is not fashionable to be a drunkard, but they will accelerate the motorcycle to $250 \mathrm{~km}$ per hour ("I am a biker"). Adolescents with nSH experience tend to repeat it habitually and identify with the trauma. Especially when peers perform SH (social modeling), and the behavior satisfies the intended function (emotional selfregulation, social signaling).

The point is, I'm a carver. There are stone, wood and metal carvers, and I am a special case. I am a carver in the same way. To my skin. It longs for that. My skin is all covered with the words: "cook", "cake", "kitten", "curls" - as if a first grader armed with a knife was learning to write on it. Sometimes - only sometimes - I laugh. When I get out of bath and casually read the word "doll" carved into the side of my leg. Or, while putting on a sweater, I suddenly see on my wrist: "harmful". G. Flynn. "Sharp objects"

$\mathrm{nSH}$ theoretical models suggest that behavior is enhanced if the benefits of SH outweigh the negative consequences. The scientific evidence supports the affect-regulatory, self-punishment, and anti-dissociative models of $\mathrm{nSH}$. 
рый, эффективный и легко осуществимый (наедине и незаметно, до поры, в любых условиях: школьном или больничном туалетах или, напротив, на миру) метод аффективной / когнитивной и социальной регуляции.

Мотивы нСX объединены четырехфункииональной моделью М. Nock $[36,85]$ с опорой на систематизированные данные структурированных опросов (самоотчетов), физиологических и клинических анализов в широком ряду выборок и контекстов.
The pragmatic hypothesis [cit. 36, 85] is the most economical: adolescents have not mastered the possible skills of coping with distress, choosing maladaptive ones (use of surfactants $\pm \mathrm{nSH}$ ), they decide on $\mathrm{SH}$ as a fast, effective and easily achievable (alone and imperceptibly, for the time being, in any conditions: school or hospital toilets or, on the contrary, in the world) method of affective / cognitive and social regulation.

Таблица 2 / Table 2

Процесс и результаты нСХ [цит. по 36, 40, 85] $\mathrm{nSH}$ process and results [cit. by $36,40,85$ ]

\begin{tabular}{|c|c|c|}
\hline $\begin{array}{c}\text { Процесс } \\
\text { Process }\end{array}$ & $\begin{array}{c}\text { Результат нСX } \\
\text { nSH results }\end{array}$ & $\begin{array}{c}\text { Комментарии } \\
\text { Comments }\end{array}$ \\
\hline $\begin{array}{l}\text { Внутриличностное } \\
\text { негативное } \\
\text { подкрепление }\end{array}$ & $\begin{array}{l}\text { Немедленные уменьшение или пре- } \\
\text { кращение, контроль мучительных } \\
\text { мыслей (обрыв руминации, в том чис- } \\
\text { ле суицидального содержания) или } \\
\text { негативных чувств (напряжения, гне- } \\
\text { ва, забывчивости, ненависти к себе } \\
\text { или «душевного онемения») в ответ } \\
\text { на психотравмирующее событие. }\end{array}$ & $\begin{array}{l}\text { Сочетание негативных эмоций, вызывающих } \\
\text { СХ: чувства душевной боли, бесполезности, } \\
\text { одиночества, тревоги и паники, гнева, вины, } \\
\text { отказа, ненависти к себе или неоднозначной } \\
\text { сексуальности. Аффективная саморегуляция } \\
\text { (самоуспокоение) через болезненное отвлече- } \\
\text { ние, перенаправляющее внимание. }\end{array}$ \\
\hline
\end{tabular}
Immediate reduction or cessation, con-

Intrapersonal negative reinforcement trol over excruciating thoughts (breaking up rumination, including suicidal content) or negative feelings (tension, anger, forgetfulness, self-loathing or "mental numbness") in response to a traumatic event.

Внутриличностное позитивное подкрепление

Появление или усиление желаемых мыслей или чувств (самостимуляция, удовлетворение от самонаказания); улучшение настроения.

Intrapersonal positive reinforcement

The appearance or intensification of desired thoughts or feelings (selfstimulation, satisfaction from selfpunishment); improved mood.

\begin{tabular}{|c|c|}
\hline $\begin{array}{l}\text { Положительное } \\
\text { подкрепление } \\
\text { межличностного } \\
\text { общения }\end{array}$ & $\begin{array}{l}\text { Появление или усиление желаемого } \\
\text { социального события (внимания). } \\
\text { Призыв о помощи и поддержке, за- } \\
\text { боте и внимании. Воссоединение со } \\
\text { сверстниками. } \\
\text { The emergence or enhancement of a } \\
\text { desired social event (attention). Call for } \\
\text { help and support, care and attention. } \\
\text { Reuniting with peers. }\end{array}$ \\
\hline $\begin{array}{l}\text { Межличностное } \\
\text { негативное } \\
\text { подкрепление }\end{array}$ & $\begin{array}{l}\text { Разрешение микросоциального кон- } \\
\text { фликта (сверстники прекратили «гно- } \\
\text { бить», родители - «воспитывать»). } \\
\text { Избегание ситуации и ответственно- } \\
\text { сти. Знак силы. }\end{array}$ \\
\hline $\begin{array}{l}\text { Interpersonal } \\
\text { negative } \\
\text { reinforcement }\end{array}$ & $\begin{array}{l}\text { Resolving microsocial conflict (peers } \\
\text { stopped bullying, parents stopped "lec- } \\
\text { turing"). Avoiding situations and respon- } \\
\text { sibilities. Sign of strength. }\end{array}$ \\
\hline
\end{tabular}

A combination of negative emotions that trigger SH: feelings of heartache, worthlessness, loneliness, anxiety and panic, anger, guilt, rejection, self-loathing, or ambiguous sexuality. Affective self-regulation (complacency) through painful distraction that redirects attention.

нСХ позволяет совладать с интернализующими симптомами и уменьшить чувства эмоционального «окоченения» или пустоты. Процесс самоуспокоения может доходить до поиска физической боли и даже, возможно, до ощущения «по ту сторону физического страдания», граничащего с чувством удовольствия.

$\mathrm{nSH}$ helps to manage internalizing symptoms and reduce feelings of emotional numbness or emptiness. The self-complacency process can go as far as seeking physical pain and perhaps even feeling "beyond physical suffering," bordering on a feeling of pleasure.

\section{Средство воздействия / когнитивного регули-} рования и социального влияния.

Самопорез как «алый крик» [97], знак беды. Межличностная модель слабо доказана; отрицается самими подростками.

A means of influence / cognitive regulation and social influence.

Self-cut as a "scarlet cry" [97], a sign of trouble.

The interpersonal model is poorly proven; denied by adolescents themselves. 
нСХ поддержано процессами положительного или отрицательного подкрепления, внутриличностными или межличностными. Естественна связь сходных функций аффективной / когнитивной и социальной регуляции $\mathrm{HCX}$ или иного дезадаптивного поведения (как расстройства пищевого поведения, употребления ПАВ) с моделями «диатез-стресс / уязвимость-стресс». Общие факторы уязвимости и при других нарушениях поведения, связанных с нСХ и друг с другом.

Мотиващия к прекращению нСХ также имеет внутри- и / или межличностную направленность. К первой относится отсутствие желаемого эмоционально стабилизирующего эффекта или ухудшение состояния; желание избавиться от «дурной привычки», «не иметь больше шрамов»; «быть более здоровой» (говорили о чувстве стыда, испытываемом во время раздевания). К межличностным мотивам прекращения $\mathrm{HCX}$ отнесено желание «не причинять боль близким», сопровождаемое стыдом и виной, ситуационно обусловленное более зрелыми и эффективными механизмами психологической защиты и совладающего поведения.

Нейробиология нСX [цит. по 48]. Показаны аномальный процесс обработки стресса у совершающих нCX и повышенный порог боли при повторных нCX на материале ПЛР взрослых, но в последние годы все больше - у подростков. Многие взрослые испытывают гипоалгезию или анальгезию при нCX при подавлении лимбических зон после болевых раздражителей. Поскольку нСХ часты для преодоления неприятных эмоциональных состояний, исследованы нейробиологические маркеры регуляции стресса. У подростков концентрации кортизола повышена утром и понижена в тесте подавления дексаметазона. У подростков с нСХ сильнее ответ кортизола на боль. Анализ взаимодействия гена и окружающей среды показал, что у носителей, по крайней мере, одного короткого аллеля в полиморфной области, связанной с транспортером серотонин, чаще тяжелый межличностный стресс. Социальная изоляция депрессивных подростков с нСX приводила к активации в различных областях мозга (медиальная префронтальная кора, парагиппокамп; дополнительная моторная зона) по сравнению с контролем здоровых и без СХ. Подростки с нСX особо чувствительны к социальным стрессам, исключению из групп. Результаты подчёркивают степень взаимодействия между нейробиологическими отклонениями и факторами риска нСХ, как издевательства. Однако невозможно судить о причинно-следственных связях без длительных исследований.

Основные сокращения:

Пограничное расстройство личности - ПРЛ
The motives of nSH are united by M. Nock's four-functional model $[36,85]$ based on systematized data of structured interviews (self-reports), physiological and clinical analyzes in a wide range of samples and contexts. nSH is supported by processes of positive or negative reinforcement, intrapersonal or interpersonal. There is a natural connection between similar functions of affective / cognitive and social regulation of $\mathrm{nSH}$ or other maladaptive behavior (such as eating disorders, substance use) with the "diathesisstress / vulnerability-stress" models. Common vulnerabilities in other behavioral disorders associated with $\mathrm{nSH}$ and with each other.

The motivation to terminate $\mathrm{nSH}$ also has an intra- and / or interpersonal orientation. The first is the absence of the desired emotionally stabilizing effect or deterioration of the state; the desire to get rid of the "bad habit", "have no more scars"; "to be healthier" (talked about the feeling of shame experienced while undressing). The interpersonal motives for the termination of $\mathrm{nSH}$ include the desire "not to hurt loved ones", accompanied by shame and guilt, situationally conditioned by more mature and effective mechanisms of psychological defense and coping behavior.

Neurobiology of $n S H$ [cit. by 48]. Anomalous stress processing in those performing $\mathrm{nSH}$ and an increased pain threshold for repeated $\mathrm{nSH}$ were shown on the material of the BPD of adults, but more and more in recent years there appear data on adolescents. Many adults experience hypoalgesia or analgesia with $\mathrm{nSH}$ when limbic zones are suppressed after pain stimuli. Since $\mathrm{nSH}$ is frequent in coping with unpleasant emotional states, neurobiological markers of stress regulation have been investigated. In adolescents, cortisol concentrations are increased in the morning and decreased in the dexamethasone suppression test. Adolescents with $\mathrm{nSH}$ have a stronger cortisol response to pain. Analysis of the interaction between the gene and the environment showed that carriers of at least one short allele in the polymorphic region associated with the serotonin transporter are more likely to have severe interpersonal stress. Social isolation of depressed adolescents with $\mathrm{nSH}$ led to activation in various brain regions (medial prefrontal cortex, parahippocampus; additional motor zone) compared with controls in healthy subjects and without SH. nSH teens are particularly sensitive to social stress and exclusion from groups. The results highlight the degree of interaction between neurobiological abnormalities and risk factors for nSH as bullying. However, it is impossible to judge causal relationships without lengthy research.

Main abbreviations:

Borderline Personality Disorder - BPD 
Посттравматическое стрессовое расстройство - ПТСР

Психоактивные вещества - ПАВ

Самповреждение (мысли, поведение) - СХ

Несуицидальное самповреждение - $\mathrm{HCX}$

Суицидальное поведение - СП

Уровень суицидов - УС

\section{Литература / References:}

1. Любов Е.Б. Экскурс в историю отношения общества к суициду / Национальное руководство по суицидологии. Под ред. Б.С. Положего. М.: МИА, 2019. С. 12-39. [Lyubov E.B. an Excursion into the history of society's attitude to suicide / National guide to suicidology. Ed. by B.S. Polozhy. M.: MIA, 2019. Pp. 12-39.] (In Russ)

2. Murray C.J., Vos T., Lozano R., et al. Disability-adjusted life years (DALYs) for 291 diseases and injuries in 21 regions, 19902010: a systematic analysis for the Global Burden of Disease Study 2010. Lancet. 2012; 380 (9859): 2197-2223. DOI: 10.1016/S0140-6736(12)61690-0

3. Hamza C.A., Stewart S.L., Willoughby T. Examining the link between nonsuicidal self-injury and suicidal behavior: a review of the literature and an integrated model. Clin Psychol Rev. 2012; 32 (6): 482-495. DOI: 10.1016/j.cpr.2012.05.003

4. Owens D., Horrocks J., House A. Fatal and non-fatal repetition of self-harm. $B r \quad J$ Psychiatry. 2002; 181 (3): 193-199. DOI: 10.1192/bjp.181.3.193

5. Raphael B. Promoting the mental health and wellbeing of children and young people. Discussion paper: Key principles and directions. National Mental Health Working Group, ed. Department of Health and Aged Care, Canberra: Commonwealth of Australia, 2000.

6. Инвестируя в будущее детей: Европейская стратегия охраны здоровья детей и подростков, 2015-2020 гг. Копенгаген: Европейское региональное бюро ВО3, 2014 http://www.euro.who.int/_data/assets/pdf_file/0003/253776/64wd 12_Rus_InvestCAHstrategy_140440.pdf

7. Patton G.C., Hemphill S.A., Beyers J.M., et al. Pubertal stage and deliberate self-harm in adolescents. J. Am. Acad. Child Adolesc. Psychiatry. 2007; 46: 508-514.

8. Stengel E. The complexity of motivations to suicidal attempts. $J$ Ment Sci. 1960; 106 (445): 1388-1393.

9. Krietman N., Philip A.E., Greer S., Bagley C.R. Parasuicide. Br J Psychiatry. 1969; 115 (523): 746-747.

10. Амбрумова А.Г., Тихоненко В.А. Диагностика суицидального поведения. Методические рекомендации. М., 1980. 55 с. [Ambrumova A.G., Tikhonenko V.A. Diagnosis of suicida behavior. Methodological recommendations. M., 1980. 55 p.] (In Russ)

11. Положий Б.С., Панченко Е.А. Суициды у детей и подростков в России: современная ситуация и пути ее нормализации. [Электронный ресурс]. Медииинская психология в России: электрон. науч. журн. 2012; 2. URL: http://medpsy.ru [Polozhy B.S., Panchenko E.A. Suicide in children and adolescents in Russia: current situation and ways of its normalization [Electronic resource]. Medical psychology in Russia: electron. scientific journal. 2012; 2. URL: http://medpsy.ru

12. Berger E., Hasking P., Martin G. Adolescents' perspectives of youth non-suicidal self-injury prevention. Youth Soc. 2017; 49: 3 22.

13. Hawton K., Saunders K.E., O’Connor R.C. Self-harm and suicide in adolescents. Lancet. 2012; 379: 2373-2382.

14. Townsend E. Self-harm in young people. Evid Based Ment Health. 2014; 17 (4): 97-99.

15. Kapur N., Cooper J., O'Connor R.C., et al. Non-suicidal selfinjury v. attempted suicide: new diagnosis or false dichotomy? $\mathrm{Br}$ J Psychiatry. 2013; 202: 326-328.

16. Salter D., Platt S. Suicidal intent, hopelessness and depression in a parasuicide population: the influence of social desirability and elapsed time. Br J Clin Psychology. 1990; 29: 361-371.

17. Nock M.K. Self-Injury. Annu Rev Clin Psychol. 2010; 6: 339363.

18. Hooley J.M., Fox K.R., Boccagno C. Nonsuicidal Self-Injury: Diagnostic challenges and current perspectives. Neuropsychiatr Dis Treat. 2020; 16: 101-112. DOI: 10.2147/NDT.S198806
Post-traumatic stress disorder - PTSD

Psychoactive substances - PAS

Self-harm (thoughts, behavior) - SH

Non-suicidal self-harm $-\mathrm{nSH}$

Suicidal Behavior - SB

Suicide rate $-\mathrm{SR}$

19. Чуприков А.П., Пилягина Г.Я., Войцех В.Ф. Глоссарий суицидологических терминов. Киев, 1999. [Chuprikov A.P., Pilyagina G.Ya., Wojciech V.F. Glossary of suicidological terms. Kiev, 1999.] (In Russ)

20. Kelley K., Byrne D., Przybyla D.P.J., et al. Chronic selfdestructiveness: conceptualization, measurement, and initial validation of the vonstruct. Motivation Emotion. 1985; 9: 135-151.

21. Menninger K.A. Man against Himself. Harcourt, Brace: NY, 1938

22. Posner K., Brodsky B., Yershova K., et al. The classification of suicidal behavior. MK Nock, ed. The Oxford handbook of suicide and self-injury: Oxford University Press, 2014: 7-22.

23. Менделевич В.Д. Психология девиантного поведения: Учебное пособие. М.: ЮНИТИ-ДАНА, 2015. 445 с. [Mendelevich V.D. Psychology of deviant behavior: Textbook. Moscow: UNITY-DANA, 2015. 445 p.] (In Russ)

24. Song B., Hu W., Hu W., et al. Physical Disorders are Associated with Health Risk Behaviors in Chinese Adolescents: A Latent Class Analysis. Int J Environ Res Public Health. 2020; 17 (6): 2139.

25. Швек Ж. Добровольные галерщики: Очерки о процессах самоуспокоения. Пер. с франц. Когито-Центр, 2015. 203 с. [Shvek Zh. Voluntary gallery owners: Essays on the processes of complacency. The Qualitative Report 2015. 203 p.]

26. Фромм Э. Анатомия человеческой деструктивности. Москва: ACT, 1998. [Fromm E. Anatomy of human destructiveness. Moscow: AST, 1998.] (In Russ)

27. Рахимкулова AC. Последствия рискованного поведения для физического и психического здоровья подростков. Девиантология. 2020; 4 (1): 3-15. [Rakhimkulova A.S. Consequences of risky behavior for the physical and mental health of adolescents. Deviant Behavior (Russia). 2020; 4 (1): 3-15.] (In Russ)

28. Madge N., Hewitt A., Hawton K., et al. Deliberate self-harm within an international community sample of young people: comparative findings from the Child \& Adolescent Self-harm in Europe (CASE) Study. J Child Psychol Psyc. 2008; 49: 667-677.

29. Tsirigotis K., Gruszczynski W., Tsirigotis-Wołoszczak M. Indirect (chronic) self-destructiveness and modes of suicide attempts. Arch Med Sci. 2010; 6 (1): 111-116.

30. Любов Е.Б., Зотов П.Б., Положий Б.С. Пандемии и суицид: Идеальный шторм и момент истины. Суицидология. 2020; 11 (1): 3-38. [Lyubov E.B., Zotov P.B., Polozhy B.S. Pandemics and suicide: a perfect storm and a moment of truth. Suicidology. 2020; 11 (1): 3-38.] (In Russ) DOI: 10.32878/suiciderus.20-11-01(38)-338

31. Любов Е.Б. Граждане под короной, или как это делается в Израиле и около. Девиантология. 2020; 4 (1): 55-91. [Lyubov E.B. Citizens under the crown, or how it is done in Israel and nearby. Deviant Behavior (Russia). 2020; 4 (1): 55-91.] (In Russ)

32. NICE Self-harm Quality standard [QS34], 2013. Available from: https://www.nice.org.uk/guidance/qs34

33. International Society for the Study of Self-Injury Definition of non-suicidal self-injury, 2007. http://www.itriples.org/isssaboutself-i.html. Accessed 28 May 2014.

34. Westers N.J., Muehlenkamp J.J., Lau M. SOARS model: risk assessment of nonsuicidal self-injury. Contemp Pediatrics. July, 2016. http://contemporarypediatrics.modernmedicine.com/contem porary-pediatrics/news/soars-model-risk-assessment-nonsuicidalself-injury. Accessed April 17, 2017.

35. Plener P.L., Kaess M., Schmahl C., et al. Nonsuicidal Self-Injury in Adolescents. Dtsch Arztebl Int. 2018; 115 (3): 23-30. DOI 10.3238/arztebl.2018.0023

36. Nock M.K., Favazza A.R. Nonsuicidal self-injury: Definition and classification. Nock MK, ed. Understanding Nonsuicidal SelfInjury: Origins, Assessment, and Treatment. Washington, DC, US: American Psychological Association; 2009: 9-18.

37. Brunner R., Kaess M., Parzer P., et al. Life-time prevalence and psychosocial correlates of adolescent direct self-injurious behav- 
ior: a comparative study of findings in 11 European countries. $J$ Child Psychol Psychiatry. 2014; 55: 337-348. DOI: 10.1111/jcpp.12166

38. Lang J., Yao Y. Prevalence of nonsuicidal self-injury in chinese middle school and high school students. A meta-analysis. Med. 2018; 97 (42): e12916. DOI: 10.1097/MD.0000000000012916

39. Swannell S.V., Martin G.E., Page A., et al. Prevalence of nonsuicidal self-injury in nonclinical samples: systematic review, metaanalysis and meta-regression. Suicide Life Threat Behav. 2014; 44: 273-303. DOI: 10.1111/sltb.120709

40. Польская Н.А. Психология самоповреждающего поведения. М.: Ленанд; 2017. [Polskaya N.A. Psychology of self-injuring behavior. Moscow: Lenand; 2017.] (In Russ)

41. Банников Г.С., Федунина Н.Ю., Павлова Т.С. и соавт Ведущие механизмы самоповреждающего поведения у подростков: по материалам мониторинга в образовательных организациях. Консультативная психология и психотерапия. 2016; 24 (3): 42-68. DOI: 10.17759/cpp.2016240304 [Bannikov G.S., Fedunina N.Yu., Pavlova T.S. et al. Leading mechanisms of self-harming behavior in adolescents: based on monitoring materials in educational organizations. Counseling psychology and psychotherapy. 2016; 24 (3): 42-68.] (In Russ)

42. Monto M.A., McRee N., Deryck F.S. Nonsuicidal Self-Injury Among a Representative Sample of US Adolescents, 2015. Am J Public Health. 2018; 108 (8): 1042-1048.

43. Glenn C.R., Klonsky E.D. Nonsuicidal self-injury disorder: an empirical investigation in adolescent psychiatric patients. $J$ Clin Child Adolesc Psychol. 2013; 42: 496-507. DOI: 10.1080/15374416.2013.794699

44. Briere J., Gil E. Self-mutilation in a clinical and general population samples: Prevalence, correlates and functions. Am J Orthopsychiatry. 1998; 68 (4); 609-620. DOI: 10.1037/h0080369

45. Gillies D., Christou M.A., Dixon A.C., et al. Prevalence and Characteristics of Self-Harm in Adolescents: Meta-Analyses of Community-Based Studies 1990-2015. J Am Acad Child Adolesc Psychiatry. 2018; 57 (10): 733-741.

46. Cipriano A., Cella S., Cotrufo P. Nonsuicidal self-injury: a systematic review. Front Psychol. 2017; 8: 1946. DOI: 10.3389/fpsyg.2017.01946

47. Klonsky E.D., Victor S.E., Saffer B.Y. Nonsuicidal self-injury: What we know, and what we need to know. Can J Psych. 2014; 59 (11): 565-568. DOI: 10.1177/070674371405901101

48. Plener P.L., Schuhmacher T., Munz L.M., Groschwitz R.C. The longitudinal course of non-suicidal self-injury and deliberate selfharm: searching for predictors A systematic review of the literature. Borderline Personal Disord Emot Dysregul. 2015; 2.

49. Geulayov G., Casey D., McDonald K.C., et al. Incidence of suicide, hospital-presenting non-fatal self-harm, and communityoccurring non-fatal self-harm in adolescents in England (the iceberg model of self-harm): a retrospective study. Lancet Psychiatry. 2018; 5 (2): 167-174. DOI: 10.1016/S2215-0366(17)30478-9

50. Pluhar E., Lois R.H., Burton E.T. Nonsuicidal self-injury in adolescents: current developments to help inform assessment and treatment. Curr Opin Pediatr. 2018; 30 (4): 483-489. DOI: 10.1097/MOP.0000000000000655

51. Carroll R., Metcalfe C., Gunnell D. Hospital presenting self-harm and risk of fatal and non-fatal repetition: systematic review and meta-analysis. PLoS One. 2014; 9 (2): e89944. DOI: 10.1371/journal.pone.0089944

52. Victor S.E., Muehlenkamp J.J., Hayes N.A., et al. Characterizing gender differences in nonsuicidal self-injury: evidence from a large clinical sample of adolescents and adults. Compr Psychiatry. 2018; 82: 53-60. DOI: 10.1016/j.comppsych.2018.01.009

53. Kaess M., Parzer P., Haffner J., et al. Explaining gender differences in non-fatal suicidal behaviour among adolescents: a population-based study. BMC Public Health. 2011; 11: 597. DOI: 10.1186/1471-2458-11-597

54. Victor S.E., Klonsky E.D. Correlates of suicide attempts among self-injurers: a meta-analysis. Clin Psychol Rev. 2014; 34 (4): 282-297. DOI: 10.1016/j.cpr.2014.03.005

55. Brown R.C., Plener P.L. Non-suicidal self-injury in adolescence. Curr Psychiatry Rep. 2017; 19 (3): 20. DOI: 10.1007/s11920017-0767-9

56. Bresin K., Schoenleber M. Gender differences in the prevalence of nonsuicidal self-injury: a meta-analysis. Clin Psychol Rev. 2015; 38: 55-64. DOI: 10.1016/j.cpr.2015.02.009
57. Valencia-Agudo F., Burcher G.C., Ezpeleta L., Kramer T. Nonsuicidal self-injury in community adolescents: a systematic review of prospective predictors, mediators and moderators. $J$ Adolesc. 2018; 65: 25-38. DOI: 10.1016/j.adolescence.2018.02.012

58. Taylor P.J., Jomar K., Dhingra K., et al. A meta-analysis of the prevalence of different functions of non-suicidal self-injury. $J A f$ fect Disord. 2018; 227: 759-769. DOI: 10.1016/j.jad.2017.11.073

59. Kraemer H.C., Kazdin A.E., Offord D.R., et al. Coming to terms with the terms of risk. Arch Gen Psychiatry. 1997; 54 (4): $337-$ 343.

60. Fox K.R., Franklin J.C., Ribeiro J.D., et al. Meta-analysis of risk factors for nonsuicidal self-injury. Clin Psychol Rev. 2015; 42: $156-167$.

61. Favazza A.R. Nonsuicidal self-injury: How categorization guides treatment. Curr Psychiatry. 2012; 11 (3): 21-26.

62. Clarke S., Allerhand L.A., Berk M.S. Recent advances in understanding and managing self-harm in adolescents [version 1; peer review: 2 approved]. F1000Research 2019, 8 (F1000 Faculty Rev): 1794. DOI: 10.12688/f1000research.19868.1

63. Инвестируя в будущее детей: Европейский план действий по предупреждению жестокого обращения с детьми, 2015-2020 гг. Копенгаген: Европейское региональное бюро ВО3; 2014 (http://www.euro.who.int/

_data/assets/pdf_file/0007/253780/64wd13_rus_InvestChildMaltr eat 140439.pdf, по состоянию на 25 декабря 2017 г.) [Investing in the future of children: European action plan for the prevention of child abuse, 2015-2020 Copenhagen: who regional office for Europe; $2014 \quad$ (http://www.euro.who.int/ _data/assets/pdf_file/0007/253780/64wd13_rus_InvestChildMaltr eat_140439. pdf, as of December 25, 2017)]

64. Fliege H., Lee J.R., Grimm A., Klapp B.F. Risk factors and correlates of deliberate self-harm behavior: a systematic review. J Psychosom Res. 2009; 66: 477-493.

65. Thomassin K., Shaffer A., Madden A., Londino D.L. Specificity of childhood maltreatment and emotion deficit in nonsuicidal selfinjury in an inpatient sample of youth. Psychiatry Res. 2016; 244: 103-108.

66. Krueger D.W. Integrating body self and psychological self: Creating a New Story in Psychoanalysis and Psychotherapy. NY: Psychology Press, 2002.

67. Gromatsky M.A., Waszczuk M.A., Perlman G., et al. The role of parental psychopathology and personality in adolescent nonsuicidal self-injury. J Psychiatr Res. 2017; 85: 15-23.

68. Шустов Д.И., Тучина О.Д., Федотов И.А., Новиков С.А. Аутоагрессивная алкогольная личность. Консультативная психология психотерапия. 2016; 24 (3): 89-109. [Shustov D. I., Tuchina O. D., Fedotov I. A., Novikov S. A. Autoaggressive alcoholic personality. Counseling psychology psychotherapy. 2016; 24 (3): 89-109.] (In Russ)

69. Kessler R.C., Angermeyer M., Anthony J.C., et al. Lifetime prevalence and age-of-onset distributions of mental disorders in the World Health Organization's World Mental Health Survey Initiative. World Psychiatry. 2007; 6: 168-176.

70. Romano E., Tremblay R.E., Vitaro F., et al. Prevalence of psychiatric diagnoses and the role of perceived impairment: findings from an adolescent community sample. J Child Psychol Psychiatry. 2001; 42: 451-461.

71. Sawyer M.G., Arney F.M., Baghurst P.A., et al. The mental health of young people in Australia: key findings from the child and adolescent component of the national survey of mental health and well-being. Aust NZ J Psychiatry. 2001; 35 (6): 806-814.

72. Buelens T., Luyckx K., Kiekens G., et al. Investigating the DSM5 criteria for non-suicidal self-injury disorder in a community sample of adolescents. J Affect Dis. 2020; 260 (1): 314-322. DOI: 10.1016/j.jad.2019.09.009

73. Crowe M. From expression to symptom to disorder: the psychiatric evolution of self-harm in the DSM. J Psychiatr Ment Health Nurs. 2014; 21: 857-858. DOI: 10.1111/jpm.12183

74. Glenn C.R., Klonsky E.D. Social context during non-suicidal selfinjury indicates suicide risk. Personality and Individual Differences. 2009; 46 (1): 25-29. DOI: 10.1016/j. paid.2008.08.020

75. Peterson J., Freedenthal S., Sheldon C., Andersen R. Nonsuicidal Self injury in Adolescents. Psychiatry (Edgmont). 2008; 5 (11): 20-26.

76. Lereya S.T., Copeland W.E., Costello E.J., Wolke D. Adult mental health consequences of peer bullying and maltreatment in 
childhood: two cohorts in two countries. Lancet Psychiatry. 2015; 2: 524-531.

77. Jarvi S., Jackson B., Swenson L., Craford H. The impact of social contagion on non-suicidal self-injury: a review of the literature. Arch Suicide Res. 2013; 17: 1-19.

78. Bandura A., ed. Psychological Modeling: Conflicting Theories.Piscataway, NJ: Aldine, 2006.

79. Lloyd-Richardson E.E., Perrine N., Dierker L., Kelley M.L. Characteristics and functions of non-suicidal self-injury in a community sample of adolescents. Psychological Medicine. 2007; 37 (8): 1183-1192. DOI: 10.1017/ S003329170700027X

80. Walsh B.W. Treating self-injury: A practical guide. NY: Guilford Press, 2006

81. Любов Е.Б., Палаева Р.И. «Молодые» суициды и интернет: хороший, плохой, злой. Суицидология. 2018; 9 (2): 72-81. [Lyubov E.B., Palayeva R.I. Suicides of youth and internet: the good, the bad and the ugly. Suicidology. 2018; 9 (2): 72-81.] (In Russ)

82. Lewis S.P., Seko Y. A double-edged sword: a review of benefits and risks of online nonsuicidal self-injury activities. J Clin Psychol. 2016; 72: 249-262.

83. Rudd M.D., Berman A.L., Joiner T.E., et al. Warning signs for suicide: theory, research, and clinical applications. Suicide Life Threat Behav. 2006; 36 (3): 255-262.

84. Franklin J.C., Ribeiro J.D., Fox K.R., et al. Risk factors for suicidal thoughts and behaviors: A meta-analysis of 50 years of research. Psychol Bull. 2017; 143 (2): 187-232.

85. Nock M.K., Green J.G., Hwang I., et al. Prevalence, correlates, and treatment of lifetime suicidal behavior among adolescents: results from the National Comorbidity Survey Replication Adolescent Supplement. JAMA Psychiatry. 2013; 70 (3): 300-310.

86. Fowler J.C. Suicide risk assessment in clinical practice: pragmatic guidelines for imperfect assessments. Psychotherapy (Chic). 2012; 49 (1): 81-90.

87. Ramchand R., Franklin E., Thornton E., et al. Opportunities to intervene? "Warning signs" for suicide in the days before dying. Death Studies. 2017; 41 (6): 368-375.
88. Любов Е.Б., Зотов П.Б., Банников Г.С. Самоповреждающее поведение подростков: дефиниции, эпидемиология, факторы риска и защитные факторы. Сообщение I. Суииидология. 2019; 10 (37): 16 - 46. [Lyubov E.B., Zotov P.B., Bannikov G.S. Self-harming behavior of adolescents: definitions, epidemiology, risk factors and protective factors. The Message I. Suicidology. 2019; 10 (4): 16-46.] (In Russ) doi.org/10.32878/suiciderus.19-1004(37)-16-46

89. Raffagnato A., Angelico C., Valentini P, et al. Using the Body When There Are No Words for Feelings: Alexithymia and Somatization in Self-Harming Adolescents. Front Psychiatry. 2020; 11: 262. DOI: $10.3389 /$ fpsyt.2020.00262

90. Favazza A.R. Bodies under Siege: Self-Mutilation in Culture and Psychiatry. Baltimore: John Hopkins Press, 1987.

91. Klonsky E.D. The functions of deliberate self-injury: a review of the evidence. Clin Psychol Rev. 2007; 27 (2): 226-239.

92. Doyle L., Sheridan A., Treacy M.P. Motivations for adolescent self-harm and the implications for mental health nurses. J Psychiatr Ment Health Nurs. 2017; 24 (2-3): 134-142.

93. Scoliers G., Portzky G., Madge N., et al. Reasons for adolescent deliberate self-harm: A cry of pain and/or a cry for help? Soc. Psychiatry Psychiatr. Epidemiol. 2009; 44: 601-607.

94. Анзье Д. Я-кожа. Пер. франц. Эрго, 2012. 302 с. [Ansie D. Iskin. Per. Frantz. Ergo, 2012. 302 p.] (In Russ)

95. Каминская Н.А. Исследования отчуждения физического «я». Консультативная психология и психотерапия. 2016; 24 (2): 8-28. [Kaminskaya N. A. Studies of alienation of the physical "I". Counseling psychology and psychotherapy. 2016; 24 (2): 8-28.] (In Russ) DOI: 10.17759/cpp.20162402002

96. Zetterqvist M., Lundh L.G., Dahlstrom O., Svedin C.G. Prevalence and function of non-suicidal self-injury (NSSI) in a community sample of adolescents, using suggested DSM-5 criteria for a potential NSSI disorder. J Abnorm Child Psychol. 2013; 41: 759-773.

97. Strong M. A Bright Red Scream: Self-mutilation and the Language of Pain. Viking Press, 1998. 232 p.

\title{
ADOLESCENTS NON-SUICIDAL SELF-INJURY: GENERAL AND PARTICULAR. Part I.
}

\author{
E.B. Lyubov, \\ P.B. Zotov \\ Moscow Institute of Psychiatry - branch of National medical research center of psychiatry \\ and narcology by name V.P. Serbsky, Moscow, Russia; lyubov.evgeny@mail.ru \\ Tyumen State Medical University, Tyumen, Russia; note72@yandex.ru
}

\section{Abstract:}

In the first part of the review, self-harming behavior ("self-harm", SH) is viewed as a spectrum of direct and indirect forms of deviant behavior with an emphasis on adolescents non-suicidal SH in comparison with older ages and taking into account the gender aspect. The prevalence, possibly growing, of SH in clinical and general population samples, functions of SH have been specified; the models (hypotheses) of SH and the relationship between non-suicidal and suicidal behavior are discussed.

Keywords: self-harm, non-suicidal self-harm, prevalence, risk factors

Вкмад авторов:

Е.Б. Аюбов: разработка дизайна исследования, обзор публикаций, написание и редактирование текста рукописи;

П.Б. Зотов: обзор публикаций по теме статьи, написание и редактирование текста рукописи.

Authors' contributions:

E.B. Lyubov: developing the research design, reviewing of publications, article writing, article editing;

P.B. Zotov: reviewing of publications of the article's theme; article writing, article editing.

Финансирование: Данное исследование не имело финансовой поддержки

Financing: The study was performed without external funding.

Конфмикт интересов: Авторы заявцяют об отсутствии конфмикта интересов.

Conflict of interest: The authors declare no conflict of interest.

Статья поступима / Article received: 02.06.2020. Принята к публикации / Accepted for publication: 19.09.2020.

Для цитирования: Любов Е.Б., Зотов П.Б. Несуицидальные самоповреждения подростков: общее и особенное. Часть I. Суицидология. 2020; 11 (3): 44-71. doi.org/10.32878/suiciderus.20-11-03(40)- 44-71

For citation: $\quad$ Lyubov E.B., Zotov P.B. Adolescents non-suicidal self-injury: general and particular. Part I. Suicidology. 2020; 11 (3): 44-71. (In Russ) doi.org/10.32878/suiciderus.20-11-03(40)-44-71 